\title{
wiiw
}

Wiener Institut für

The Vienna Institute

Internationale

for International

Wirtschaftsvergleiche

Economic Studies

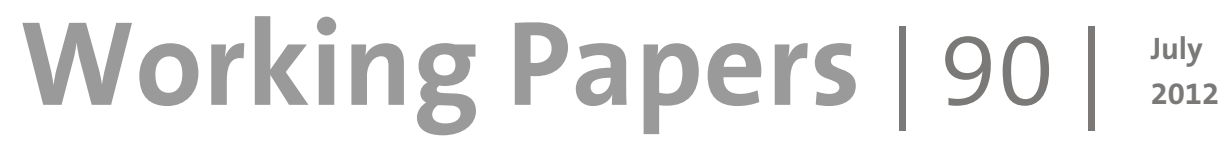

Neil Foster, Johannes Pöschl and Robert Stehrer

\section{Offshoring and the Elasticity of Labour Demand}




\section{wiiw Working Papers published since 2009.}

No. 90 N. Foster, J. Pöschl and R. Stehrer: Offshoring and the Elasticity of Labour Demand. July 2012

No. 89 N. Foster, J. Pöschl and R. Stehrer: Manufacturing Productivity: Effects of Service Sector Innovations and Institutions. July 2012

No. 88 A. Breitwieser and N. Foster: Intellectual Property Rights, Innovation and Technology Transfer: A Survey. June 2012

No. 87 N. Foster: On the Volume and Variety of Intra-Bloc Trade in an Expanded European Union. June 2012

No. $86 \quad$ N. Foster, R. Stehrer and G. de Vries: Offshoring and the Skill Structure of Labour Demand. June 2012

No. 85 M. Holzner and F. Peci: Measuring the Effects of Trade Liberalization in Kosovo. June 2012

No. 84 S. M. Leitner and R. Stehrer: Labour Hoarding during the Crisis: Evidence for selected New Member States from the Financial Crisis Survey. June 2012

No. 83 E. Bekkers and J. Francois: Bilateral Exchange Rates and Jobs. June 2012

No. 82 E. Bekkers, J. Francois and M. Manchin: Import Prices, Income, and Inequality. June 2012

No. 81 R. Stehrer: Trade in Value Added and the Valued Added in Trade. June 2012

No. 80 R. Stehrer, N. Foster and G. de Vries: International spillovers in a world of technology clubs. June 2012

No. 79 R. Stöllinger: International spillovers in a world of technology clubs. May 2012

No. 78 S. Leitner and R. Stehrer: Access to Finance and Composition of Funding during the Crisis: A firm-level analysis for Latin American countries. February 2012

No. 77 E. Bekkers and R. Stehrer: Reallocation Gains in a Specific Factors Model with Firm Heterogeneity. December 2011

No. $76 \quad$ M. Holzner and F. Peci: The Impact of Customs Procedures on Business Performance: Evidence from Kosovo. August 2011

No. 75 C. Hornok: Need for Speed: Is Faster Trade in the EU Trade-Creating? April 2011

No. 74 S. Leitner and R. Stehrer: Subgroup and Shapley Value Decompositions of Multidimensional Inequality An Application to Southeast European Countries. March 2011

No. 73 S. M. Leitner and R. Stehrer: Do Exporters Share Part of their Rents with their Employees? Evidence from Austrian Manufacturing Firms. February 2011

No. 72 S. M. Leitner, J. Pöschl and R. Stehrer: Change begets change: Employment effects of technological and nontechnological innovations - A comparison across countries. January 2011

No. $71 \quad$ M. Holzner: Inequality, Growth and Public Spending in Central, East and Southeast Europe. October 2010

No. $70 \quad$ N. Foster, J. Pöschl and R. Stehrer: The Impact of Preferential Trade Agreements on the Margins of International Trade. September 2010

No. 69 L. Podkaminer: Discrepancies between Purchasing Power Parities and Exchange Rates under the Law of One Price: A Puzzle (partly) Explained? September 2010

No. 68 K. Hauzenberger and R. Stehrer: An Empirical Characterization of Redistribution Shocks and Output Dynamics. August 2010

No. 67 R. Stöllinger, R. Stehrer and J. Pöschl: Austrian Exporters: A Firm-Level Analysis. July 2010

No. 66 M. Holzner: Tourism and Economic Development: the Beach Disease? June 2010

No. 65 A. Bhaduri: A Contribution to the Theory of Financial Fragility and Crisis. May 2010

No. 64 L. Podkaminer: Why Are Goods Cheaper in Rich Countries? Beyond the Balassa-Samuelson Effect. April 2010

No. 63 K. Laski, J. Osiatynski and J. Zieba: The Government Expenditure Multiplier and its Estimates for Poland in 2006-2009. March 2010

No. 62 A. Bhaduri: The Implications of Financial Asset and Housing Markets on Profit- and Wage-led Growth: Some Results in Comparative Statics. February 2010

No. $61 \quad$ N. Foster and R. Stehrer: Preferential Trade Agreements and the Structure of International Trade. January 2010

No. 60 J. Francois and B. Hoekman: Services Trade and Policy. December 2009

No. 59 C. Lennon: Trade in Services: Cross-Border Trade vs. Commercial Presence. Evidence of Complementarity. November 2009

No. $58 \quad$ N. Foster and J. Pöschl: The Importance of Labour Mobility for Spillovers across Industries. October 2009 
Neil Foster, Johannes Pöschl

Neil Foster and Johannes Pöschl are research and Robert Stehrer

economists at the Vienna Institute for International Economic Studies (wiiw). Robert Stehrer is wiiw Deputy Director of Research.

Offshoring and the Elasticity of Labour Demand 



\section{Contents}

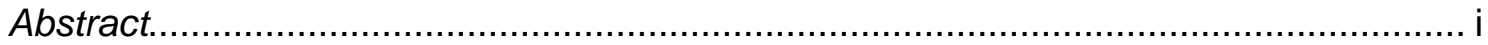

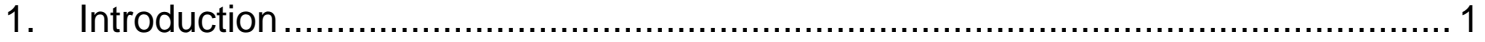

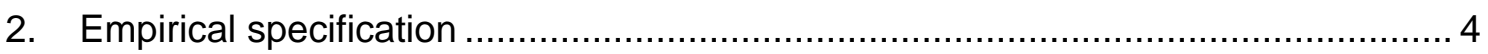

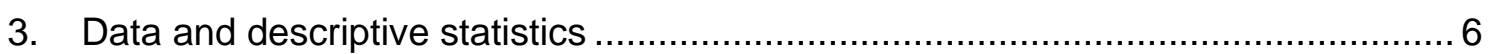

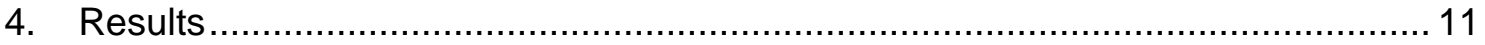

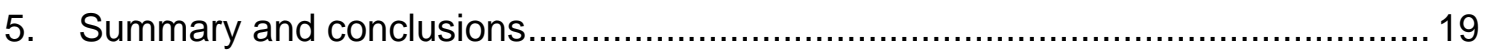

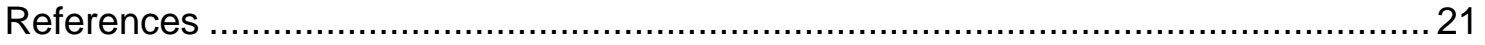

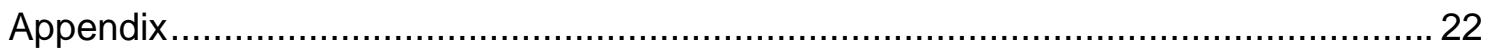




\section{List of Tables and Figures}

Table 1 Average growth rate of employment by country (in \%) ................................. 10

Table 2 Narrow offshoring for all industries ................................................... 15

Table 3 Narrow and broad offshoring for all industries....................................... 15

Table 4 Manufacturing and services offshoring for all industries............................. 16

Table 5 Narrow and broad offshoring for different industry types.......................... 18

Table 6 Manufacturing and services offshoring for different industry types .............. 18

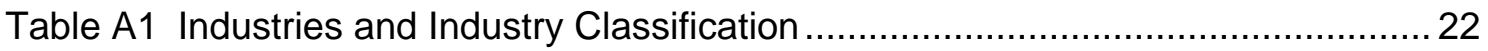

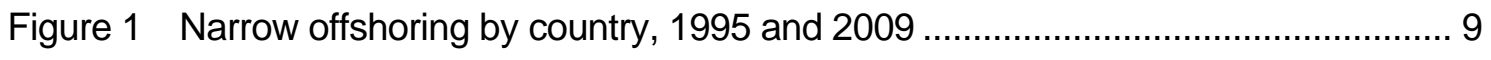

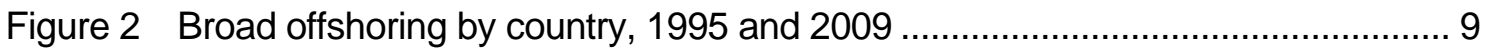

Figure 3 Trend in the conditional wage elasticity ....................................................... 12

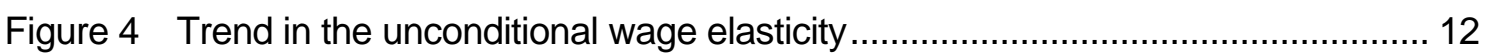




\begin{abstract}
This paper examines the impact of offshoring on labour elasticities for a sample of 40 countries over the period 1995-2009 using the recently compiled World Input-Output Database (WIOD). Including measures of narrow and broad offshoring, as well as indicators of manufacturing and services offshoring, in conditional and unconditional labour demand equations we find that offshoring has an overall neutral or slightly positive effect on employment. This result hides differences across industry types and across employment types however, with additional results indicating a negative effect of services offshoring in many industry types. Positive effects of other offshoring measures are found in high-tech manufacturing and for high-educated employment in particular.
\end{abstract}

Keywords: labour demand elasticities, offshoring

JEL classification: F16, J23 

Neil Foster, Johannes Pöschl and Robert Stehrer

\section{Offshoring and the elasticity of labour demand}

\section{Introduction}

The ongoing process of globalization has seen the increasing frequency and extent of international outsourcing - or offshoring - of production, involving the contracting out of activities that were previously performed within a production unit to foreign subcontractors. Feenstra and Hanson (1996) and Campa and Goldberg (1997) showed that between 1972 and 1990 offshoring more than doubled in the USA, Canada and the UK. This trend of increasing offshoring of production activities was also evident in a number of other developed and developing countries and continued throughout the 1990s and 2000s. Such offshoring is expected to bring about gains for consumers in the form of lower prices and for producers through increased productivity and low-cost intermediate inputs. ${ }^{1}$ There remains a concern however that the costs of offshoring fall disproportionately on workers and in the developed world at least on low-skilled workers in particular. At the same time as offshoring was increasing the relative wages and employment of skilled workers were also observed to be increasing in many developed and developing countries (see Feenstra, 2007). Many argued that these two phenomena were related with firms in the developed world offshoring their low-skilled intensive production stages to low-wage developing countries, thereby lowering the demand for low-skilled labour. ${ }^{2}$ Others argue that offshoring has played a relatively minor role in changing relative labour demands, with skill-biased technological change (SBTC) considered to be the most important factor. An empirical literature on the impact of offshoring on labour markets exists, with the majority of this work concerned with offshoring's impact on the wage or cost shares of low- and high-skilled workers, that is, on the skill composition of labour demand. This literature tends to support the view that offshoring has been one of the factors lowering the demand for low-skilled workers in developed countries, but that it has not been the major cause of this shift in relative labour demand (Slaughter, 2000; Feenstra, 2007).

In this paper we consider the impact of offshoring on the elasticity of labour demand. Hijzen and Swaim (2010) identify a number of reasons why this issue is particularly relevant. They argue that to the extent that offshoring increases the labour elasticity of demand it may help explain why workers may feel increasingly insecure, since the wage and employment effects of a shock will be amplified by the higher elasticity of demand. In addition,

\footnotetext{
Amiti and Wei (2005) note that productivity can increase due to both compositional and structural changes. In the former case, firms shift relatively inefficient parts of the production process leaving them to concentrate on parts in which they are relatively efficient increasing overall efficiency, while in the latter offshoring can provide access to new input varieties, which can increase the productivity of remaining workers.

2 Since relatively low-skilled stages of production in the developed world may still be higher than most skill-intensive stages of production in the developing country, such offshoring may also lower demand for low-skilled labour in the developing country.
} 
a higher elasticity of demand will tend to reduce worker's bargaining power and may limit the scope for risk-sharing arrangements between workers and firms. From a theoretical perspective there are two main effects of offshoring on employment. The first is a 'technology' or 'substitution' effect that reflects the destruction of jobs that occurs when firms relocate part of their production activities overseas. The second is a 'scale' effect that captures the creation of jobs following the expansion in industry output that may arise as a result of the productivity gains from offshoring. A third indirect 'substitution effect' may also be relevant, in which offshoring affects domestic sub-contracting relationships, thus leading to a negative impact on employment in other domestic sectors (Cappariello, 2010). Such an effect would imply that there would be negative employment effects on an industry of offshoring in other domestic industries. An alternative view (Arndt, 1997) would suggest that the positive productivity effect of offshoring may lead to increased demand for intermediate goods from the domestic economy also, which may offset this indirect 'substitution effect'. In the analysis that follows we concentrate on the direct effects, leaving the possibility of spillover effects from offshoring on other domestic industries to future work.

A small number of relatively recent studies examine empirically the impact of globalization on the level of employment using industry-level data, examples including Slaughter (2001), Bruno et al (2004), Molnar et al (2007) and Hijzen and Swaim (2010). Slaughter (2001) considers a large number of economic integration measures - including offshoring measures - for the case of the US and finds some evidence that labour demand has become more elastic as integration increased. Bruno et al (2004) concentrate on measures of import penetration for seven OECD countries and find that in the majority of cases there is no significant relationship between import penetration and labour demand. Molnar et al (2007) do something similar to Bruno et al (2004) but use measures of outward FDI rather than import penetration. Their results indicate that labour demand elasticities have increased in response to FDI in manufacturing industries, but declined in services industries. The paper of Hijzen and Swaim (2010) concentrates explicitly on offshoring when considering the impact of globalization on labour demand and is the paper upon which the approach adopted subsequently is based. Hijzen and Swaim (2010) examine the relationship between offshoring and industry employment using data on 17 high-income OECD countries for 1995 and 2000. They distinguish between a narrow (i.e. intra-industry) and broad (i.e. inter-industry) measure of offshoring, often finding that the narrow measure impacts negatively upon labour demand, while the broad offshoring measure tends to have no significant impact. They argue that this makes intuitive sense since intra-industry offshoring is more likely to substitute for domestic value added previously performed in that industry. ${ }^{3}$

Hijzen and Swaim (2007) find that while intra-industry offshoring reduces the labour-intensity of production, it does not impact on the overall level of employment. In their analysis, inter-industry offshoring does not affect labour-intensity but has a positive effect on overall sectoral employment. Results reported by OECD (2007) find that offshoring lowers the conditional and unconditional demand for labour in OECD countries. 
A subset of these papers considers the distinction between offshoring of manufacturing stages of production and offshoring of services, the latter of which has increased significantly in recent years. Amiti and Wei (2005) examine the impact of service offshoring on both productivity and employment in the USA. While the results indicate that service offshoring has a positive impact on productivity, the authors find some evidence of a negative impact on employment, though this effect disappears when sectors are aggregated. The impact of manufacturing offshoring on employment is positive, when significant. Schöller (2007) considers the impact of service offshoring on manufacturing employment in Germany over the period 1991-2000 and finds that service offshoring had a negative impact on manufacturing employment.

Some recent studies also consider the possibility of heterogeneity in the impact of offshoring on employment. Falk and Wolfmayr (2005) for example, examine the impact of offshoring to low-wage countries on employment for seven EU countries over the period 19952000. They find that importing intermediates from the same industry from low-wage countries has a negative and significant impact on total employment. When splitting their sample of industries into low- and high-skill intensity industries they find that while the employment effects of offshoring are negative and significant in low-skill intensity industries, they are not significant in high-skill intensive industries. Cadarso et al (2008) on the other hand, find in the case of Spain that a significant negative impact of offshoring on employment is found only in the case of narrow offshoring in medium- and high-tech industries and only when inputs come from Central and Eastern European countries.

The current paper uses the recently compiled World Input Output Database (WIOD) to examine whether offshoring impacts upon the elasticity of labour demand in 40 developed and developing countries. The current paper follows closely the approach of Hijzen and Swaim (2010), with the data in the WIOD allowing us to add to these earlier results in a number of ways. In particular, while Hijzen and Swaim (2010) were restricted to considering the years 1995 and 2000 only due to the availability of Input-Output tables, the WIOD reports time-series of international Supply and Use tables and international Input-Ouput tables for each year between 1995 and 2009. The WIOD data also has information on 40 countries (plus a rest of the world), which allows us to consider a larger number of countries than was possible for Hijzen and Swaim (2010). The WIOD data also potentially allows one to decompose offshoring by source country and in to a manufacturing and services component. In our analysis we consider separately the impact of manufacturing and services offshoring on demand elasticities.

While most services activities were long considered to be non-tradable, in recent years services trade has risen rapidly. Offshoring of services activities has also begun to rise relatively quickly in recent years. This has lead to the fear that services offshoring may impact negatively upon skilled employment and skilled wages in developed countries, yet 
to date there has been little research examining the impact of services offshoring on labour markets (notable exceptions being Amiti and Wie, 2005; and Schöller, 2007). ${ }^{4}$

We estimate labour demand equations for total employment, examining the impact of both narrow and broad measures of offshoring (as well as a manufacturing and services measure of offshoring) on labour demand elasticities for total employment. In addition, we also estimate the labour demand equations for employment by skill level (i.e. low-, medium- and high-educated labour). Furthermore, in order to allow the labour demand functions to vary across industries, we report results for different industry types, classifying industries as low, medium- or high-tech and further differentiating by manufacturing and services industries. Our results indicate that, in general, offshoring has an overall neutral or slightly positive effect on employment. This result hides differences across industry types and across employment types however. While positive employment effects of alternative measures of offshoring are found in high-tech manufacturing and for high-educated employment in particular, we also obtain results indicating a negative employment effect of services offshoring. This final result is consistent with results reported for the USA and Germany by Amiti and Wei (2005) and Schöller (2007) respectively.

The remainder of the paper is set out as follows: Section 2 describes the econometric approach that we adopt; Section 3 provides information on the data used in the analysis and reports some initial descriptive statistics; Section 4 reports the main results from the analysis; and Section 5 concludes.

\section{Empirical specification}

The empirical approach that we adopt to consider the impact of offshoring on employment is very similar to the approaches adopted in the above mentioned studies. This involves estimating two models of labour demand - the conditional and unconditional labourdemand models. The major difference in our analysis is that in addition to estimating the model for total employment we also estimate the model for employment of different skill levels.

In the conditional model, the profit-maximizing level of labour demand is determined by minimizing the costs of production conditional on output, i.e. industry $i$ 's production costs are a function of factor prices and output. The conditional model of labour demand thus allows one to assess the technology effect of offshoring by keeping output constant. In a conditional demand function we expect that if offshoring increases productivity, then this

\footnotetext{
Amiti and Wei (2005) for example note that in the USA support for free trade among white collar workers dropped significantly in the early 2000s. Jensen (2011) argues that service offshoring is unlikely to impact significantly on highskilled labour in the US since it has a comparative advantage in high-tech services. The service offshoring that is likely to take place therefore will be in low-tech services.
} 
will have a negative effect on the demand for labour since fewer inputs are needed to produce the same amount of output. In the unconditional model it is assumed that firms maximize profits, by choosing the optimal mix of input quantities and the level of output for given input and output prices. In the case of labour demand, this corresponds to adjusting hiring so that the marginal value product of labour equals the wage. The unconditional model thus allows one to analyse the total effect of offshoring on labour demand. Hijzen and Swaim (2007) argue therefore that differences in results between the two models thus gives a measure of the scale effect associated of offshoring.

The conditional labour demand equation can be written as:

$$
\ln L_{i c t}=\alpha_{0}+\sum_{j=1}^{J} \alpha_{j} \ln w_{i j c t}+\beta_{k} \ln k_{i c t}+\beta_{y} \ln y_{i c t}+\sum_{i=l}^{L} \gamma_{l} \ln z_{i l c t}
$$

where $L_{i c t}$ is industry-level labour demand in industry $i$ in country $c$ in time $t, w$ is the nominal price of variable factors (the wage and the price of materials), $k$ is the capital stock, $y$ is gross output, and $z$ refer to demand shifters, namely our indicators of offshoring. In our analysis we include measures of both narrow and broad offshoring as well as distinguishing between manufacturing and services offshoring. The set of demand shifters, $z$, often include measures of SBTC, for example a measure of the ICT capital stock or some measure of R\&D intensity. Unfortunately, the WIOD doesn't report information on variables that could be used to capture SBTC for developing and transition countries. Moreover, we are not aware of an alternative database that reports such variables for all of the countries and industries covered in our analysis. To control for SBTC therefore we adopt an alternative approach, including a set of country-industry time trends (i.e. for each industry within each country we include a separate time trend), which control for excluded factors that lead to changes in labour demand over time for each industry in each country, one such factor being SBTC. We further estimate this model for the three different types of labour (low-, medium- and high-skilled), in which case the dependent variable is industry-level labour demand for a particular labour type and the wage variable is the average wage of that type of labour.

The unconditional (or capital-constrained) labour demand model is given by:

$$
\ln L_{i c t}=\alpha_{0}+\sum_{j=1}^{J} \alpha_{j} \ln w_{i j c t}+\beta_{k} \ln k_{i c t}+\sum_{i=l}^{L} \gamma_{l} \ln z_{i l c t}
$$

Following Hijzen and Swaim (2010) the output price is excluded from the unconditional model since in imperfectly competitive industries it is considered endogenous as it will be a decreasing function of output. By substituting out the quantity of output this equation allows for scale effects (Hijzen and Swaim, 2007). The net effect of offshoring will then depend upon whether the scale effects are large enough to outweigh the substitution and productivity effects. Once again, this equation will be estimated for total labour and for the three different labour types. 
Adding a random disturbance term to the above equations allows us to estimate these models. In the regression analysis that follows we adopt the fairly standard approach of differencing the data to account for time-invariant fixed effects. ${ }^{5}$ We further include year dummies to capture any time specific heterogeneity and as mentioned above countryindustry time trends to control for SBTC and other excluded country-industry specific factors that may affect labour demand, such that our final estimating equations are:

$\Delta \ln L_{i c t}=\alpha_{0}+\sum_{j=1}^{J} \alpha_{j} \Delta \ln w_{i j c t}+\beta_{k} \Delta \ln k_{i c t}+\beta_{y} \Delta \ln Y_{i c t}+\sum_{i=l}^{L} \gamma_{l} \Delta \ln z_{i l c t}+\sum_{i=1}^{I} \sum_{c=1}^{C} \varphi_{i c} T_{i c t}+\delta_{t}+\varepsilon_{i c t}$

and

$\Delta \ln L_{i c t}=\alpha_{0}+\sum_{j=1}^{J} \alpha_{j} \Delta \ln w_{i j c t}+\beta_{k} \Delta \ln k_{i c t}+\sum_{i=l}^{L} \gamma_{l} \Delta \ln z_{i l c t}+\sum_{i=1}^{I} \sum_{c=1}^{C} \varphi_{i c} T_{i c t}+\delta_{t}+\varepsilon_{i c t}$

where $\Delta$ indicates the first difference of a variable. Since the two equations are specified as log-linear, the coefficients can be interpreted as elasticities.

\section{Data and descriptive statistics}

The basic data source for our analysis is the recently completed World-Input-OutputDatabase (WIOD), which reports data on socio-economic accounts, input-output tables and bilateral trade data across 35 industries and 40 countries over the period 1995-2009. ${ }^{6}$ These data result from an effort to bring together information from national accounts statistics, supply and use tables, data on trade in goods and services and corresponding data on factors of production (capital and labour by educational attainment categories). The starting point for the WIOD data are national supply and use tables (SUTs) which have been collected, harmonized and standardized for 40 countries (the 27 EU countries, Australia, Brazil, Canada, China, India, Indonesia, Japan, Korea, Mexico, Russia, Taiwan, Turkey and the US) over the period 1995-2009. These tables contain information on the supply and use of 59 products in 35 industries together with information on final use (consumption, investment) by product, value added and gross output by industry. These tables have been benchmarked to time series of national accounts data on value added and gross output to allow for consistency over time and across countries. These tables provide information on the supply and use of products by industry for each country. Using detailed trade data the use tables are then split up into domestic and imported sourcing components, with the latter further split by country of origin. Data on goods trade were collected from the UN COMTRADE database at the HS 6-digit level. These detailed bilateral trade data allow one to differentiate imports by use categories (intermediates, consumption and investment goods) by applying a modified categorization based on broad end-use categories at the product classification. Bilateral trade in services data were collected from various sources. Services trade data are only available from Balance of Payments (BoP) statistics

\footnotetext{
5 Other possibilities include the use of fixed effects regression models including time, industry and country fixed effects and using long differenced data (i.e. five-year differences).

6 See www.wiod.org
} 
providing information at a detailed level only in BoP categories. Using a correspondence these data were merged to the product level data provided in the supply and use tables. The differentiation into use categories of services imports was based on information from existing import use or import input-output tables. Combining the information from the bilateral trade data by product and use categories with the supply and use tables resulted in a set of 40 international use tables for each year. This set of international supply and use tables was then transformed into an international input-output table using standard procedures. A rest-of-the-world was also estimated using available statistics from the UN and included in this table to account for world trade and production. This results in a world input-output database for 41 countries (including a rest-of-the world) and 35 industries. Additional data allow for the splitting up of value added into capital and labour income and the latter into low, medium and high educated workers. These data are available both in factor income and physical input terms.

In our analysis we make some small departures from the WIOD, and in particular we drop some industries from the analysis. While the offshoring measures defined below are calculated using intermediate inputs from all 35 industries, in the regression analysis below we include only 29 industries. ${ }^{7}$ The industries that are dropped are the services industries $L$ to $P$. These industries are largely non-market services where offshoring is less likely to be a significant activity. We further drop industry 23 (i.e. Coke, Refined Petroleum and Nuclear Fuel) from our analysis. For a number of countries this industry shows very low levels of value-added, which often leads to very large values for the offshoring measures. To avoid these outliers affecting our results we drop this industry from the analysis. ${ }^{8}$

When measuring offshoring the majority of existing studies focus on some measure of trade in intermediates, though as Hijzen and Swaim (2007) note this ignores the offshoring of assembly activities. In our analysis we use data from input-output tables, which allow one to measure the intermediate input purchases by each industry from each industry. In terms of the measures of offshoring Feenstra and Hanson (1999) distinguish between narrow and broad offshoring, where the former considers imported intermediates in a given industry from the same industry only, while the latter considers imported intermediates from all industries. Feenstra and Hanson (1999) prefer the narrow definition as it is thought to be closer to the essence of fragmentation, which necessarily takes place within the industry. ${ }^{9}$ In our analysis we will consider both measures of offshoring. Following Hijzen and

The 35 industries are listed in Table A1 of the Appendix.

8 As it turns out including this industry (and the excluded service industries) doesn't affect our results qualitatively. These results are available upon request.

9 Hijzen et al (2005) note that this distinction is not without problems, most notably due to the way industries are defined in the data. They consider the example of two industries in which outsourcing is important, namely 'motor vehicles and parts' and 'textiles', noting that while 'motor vehicles and parts' is a single industry in the UK IO table, 'textiles' consists of up to ten industries. 
Swaim (2007) a measure of narrow offshoring (or intra-industry offshoring) for industry $i$, $I I M_{i}^{N}$, can be calculated as:

$$
I I M_{i}^{N}=\frac{o_{k=i}}{V_{i}}
$$

where $O$ refers to imported intermediate purchases from industry $k=i$ by industry $i$, and $V$ refers to value-added. Similarly, we can define broad offshoring (or inter-industry offshoring) for industry $i, I I M_{i}^{B}$, as:

$$
I I M_{i}^{B}=\frac{\sum_{k=1}^{K} o_{k \neq i}}{V_{i}}
$$

In our analysis we also follow Amiti and Wei (2005) and Schöller (2007) and further distinguish between inter-industry offshoring of manufacturing and services. To do this we define a measure of inter-industry offshoring in manufactures as:

$$
I I M_{i}^{M}=\frac{\sum_{k=1}^{K} O_{k \neq i}^{M}}{V_{i}}
$$

where $O^{M}$ refers to imported intermediates from the subset of manufacturing industries only (these are industries $15 \mathrm{t} 16$ through $36 \mathrm{t} 37$ - see Table A1 of the Appendix).

In order to measure service offshoring we adopt a measure similar to Amiti and Wei (2005) proxying service offshoring (industries $E$ through $P$ ) with the share of imported services in total input purchases, that is:

$$
I I M_{i}^{S}=\frac{\sum_{k=1}^{K} o_{k i}^{S}}{I I_{i}}
$$

where $I I_{i}$ refers to the value of intermediate inputs in industry $i$ and $O_{k i}^{S}$ to imported inputs from service sector $k$ in industry $i$.

Figure 1 plots the average level of narrow offshoring across industries in each country for the years 1995 and 2009. The figure indicates that imported intermediates are a significant feature of production in our sample of countries, but that there exists a great deal of heterogeneity in the extent of intra-industry offshoring across countries, being relatively low in both large developed and developing countries in 1995 (e.g. India, Brazil, Japan, the USA and Russia) and relatively high in small economies in that year (e.g. Belgium, Estonia, Luxembourg, Latvia and Malta). The figure also reveals that narrow offshoring has shown a tendency to increase across countries over the period considered, increasing in 30 of the 40 countries considered. The increase in offshoring has been particularly large in a number of central European economies, most notably the Czech Republic, Hungary and Slovakia. The figures for broad offshoring reported in Figure 2 also reveal large differences in the extent of broad offshoring across countries. The overall tendency for broad offshoring to increase is even stronger than that for the narrow measure however, increasing in 37 of the 40 countries. 
Figure 1

Narrow offshoring by country, 1995 and 2009

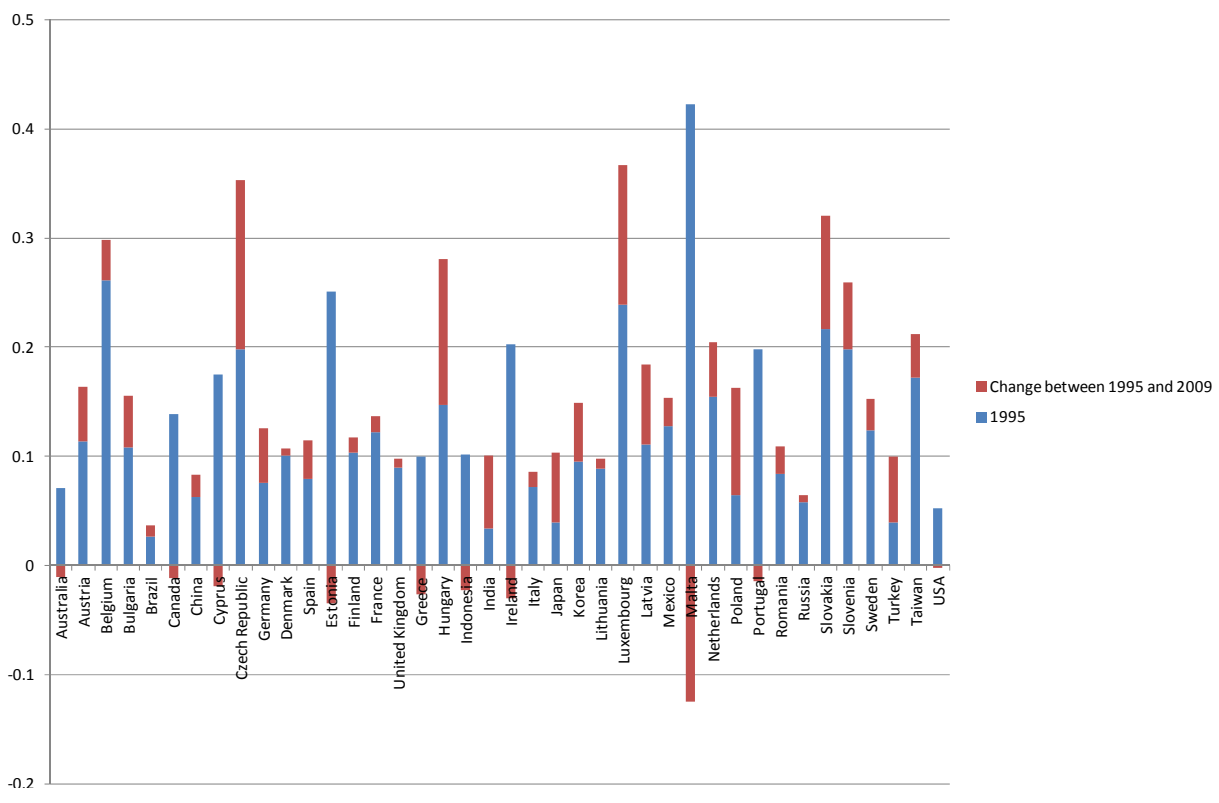

Figure 2

Broad offshoring by country, 1995 and 2009

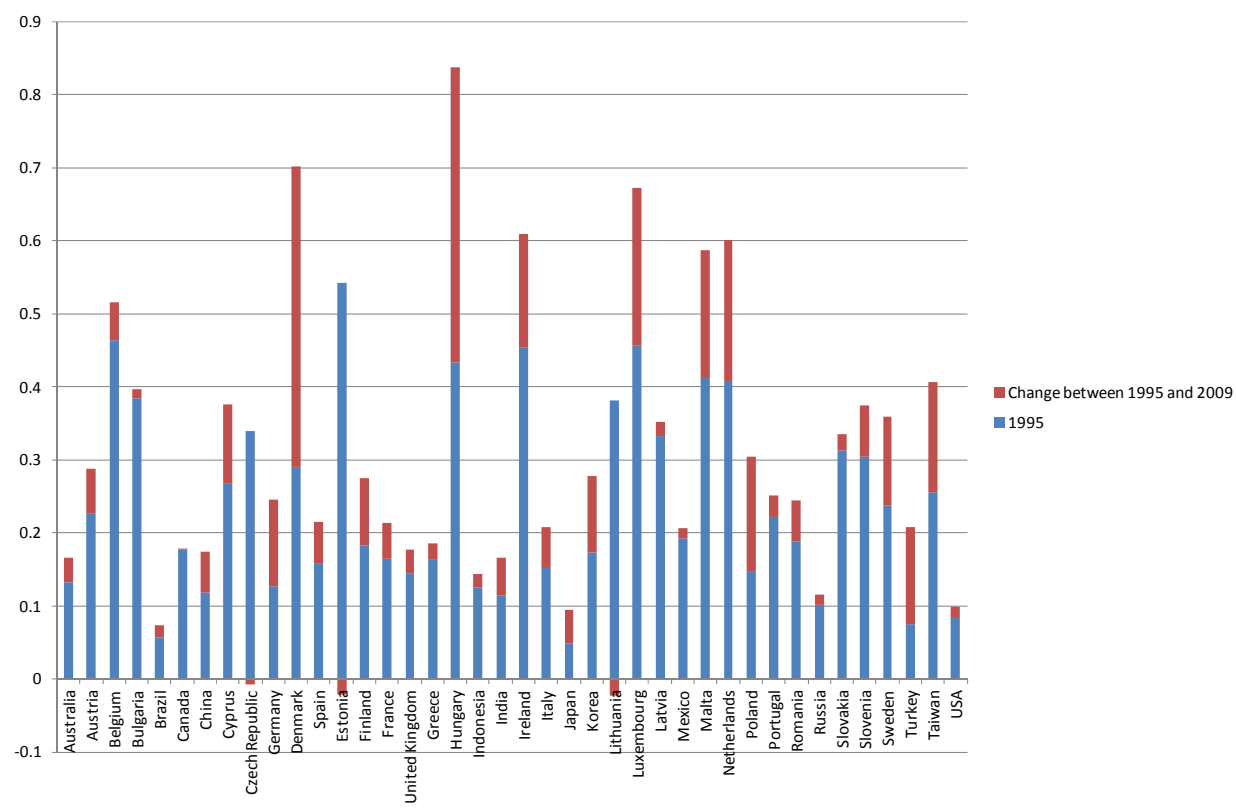

Our measure of labour demand is based upon hours worked, and is again available from the (socio-economic accounts of the) WIOD. In the analysis below we use either total hours worked or total hours worked by each of the labour types. Table 1 reports the average growth rate of total employment (in hours worked) for each of the countries in our sample, along with the average growth rates of employment for the different skill types. The table indicates that while total employment has been growing relatively rapidly for many low- and middle-income countries - most notably Brazil, China, India, Indonesia and 
Mexico - in many developed countries the growth of employment has either been stagnant or negative, particularly so in the case of Japan. The table also highlights the now wellknown fact that in the recent period low-skilled employment has been declining in most developed (but also lesser-developed) countries in the sample. The main exceptions to this are China, India, Indonesia, Latvia and to a lesser extent Mexico. At the same time, in the majority of countries we observe positive growth rates of medium-skilled employment, and in the vast majority of cases we observe large positive growth rates of high-skilled employment. This is also true for developing countries such as China and India, with only Estonia and Japan experiencing negative growth rates of high-skilled employment.

Table 1

\begin{tabular}{|c|}
\hline \\
\hline \\
\hline \\
\hline \\
\hline \\
\hline \\
\hline \\
\hline \\
\hline \\
\hline \\
\hline \\
\hline \\
\hline \\
\hline \\
\hline \\
\hline \\
\hline \\
\hline \\
\hline \\
\hline \\
\hline \\
\hline \\
\hline \\
\hline \\
\hline \\
\hline \\
\hline \\
\hline \\
\hline \\
\hline \\
\hline \\
\hline \\
\hline \\
\hline \\
\hline \\
\hline \\
\hline \\
\hline \\
\hline \\
\hline \\
\hline \\
\hline Country \\
\hline Australia \\
\hline Austria \\
\hline Belgium \\
\hline Bulgaria \\
\hline Brazil \\
\hline Canada \\
\hline China \\
\hline Cyprus \\
\hline Czech Republic \\
\hline Germany \\
\hline Denmark \\
\hline Spain \\
\hline Estonia \\
\hline Finland \\
\hline France \\
\hline United Kingdom \\
\hline Greece \\
\hline Hungary \\
\hline Indonesia \\
\hline India \\
\hline Ireland \\
\hline Italy \\
\hline Japan \\
\hline Republic of Korea \\
\hline Lithuania \\
\hline Luxembourg \\
\hline Latvia \\
\hline Mexico \\
\hline Malta \\
\hline Netherlands \\
\hline Poland \\
\hline Portugal \\
\hline Romania \\
\hline Russia \\
\hline Slovakia \\
\hline Slovenia \\
\hline Sweden \\
\hline Turkey \\
\hline Taiwan \\
\hline USA \\
\hline
\end{tabular}

\section{Average growth rate of employment by country (in \%)}

\begin{tabular}{|c|c|c|c|}
\hline Total employment & Low educated & Medium educated & High Educated \\
\hline 1.075 & -0.105 & 1.935 & 3.877 \\
\hline-0.265 & -2.576 & -0.299 & 4.567 \\
\hline-1.190 & -5.712 & 0.977 & 2.094 \\
\hline-0.062 & -1.235 & 2.346 & 4.893 \\
\hline 1.749 & -1.672 & 5.782 & 5.047 \\
\hline-0.331 & -5.558 & -0.588 & 3.080 \\
\hline 3.024 & 1.982 & 3.314 & 8.791 \\
\hline 0.063 & -1.627 & 1.516 & 0.431 \\
\hline-0.677 & -3.948 & -0.707 & 2.333 \\
\hline-1.614 & -2.617 & -1.857 & -0.003 \\
\hline-1.060 & -0.696 & -2.352 & 2.052 \\
\hline 0.961 & -2.081 & 3.970 & 5.680 \\
\hline-1.808 & -2.944 & -1.733 & -1.259 \\
\hline-0.284 & -3.950 & 0.640 & 1.359 \\
\hline-0.932 & -4.204 & -0.565 & 3.150 \\
\hline-1.823 & -5.159 & -1.065 & 1.650 \\
\hline 0.145 & -1.842 & 1.816 & 2.825 \\
\hline-0.467 & -3.414 & -0.334 & 2.514 \\
\hline 2.842 & 1.766 & 5.488 & 7.308 \\
\hline 3.173 & 2.297 & 3.435 & 6.198 \\
\hline 1.189 & -2.171 & 0.742 & 6.964 \\
\hline-0.198 & -2.870 & 2.192 & 5.637 \\
\hline-2.853 & -7.279 & -2.492 & -0.784 \\
\hline-0.755 & -6.377 & -0.923 & 3.161 \\
\hline-0.190 & -2.912 & -0.418 & 1.362 \\
\hline 2.884 & -1.690 & 5.643 & 5.742 \\
\hline 2.895 & 1.537 & 2.964 & 3.740 \\
\hline 2.593 & 1.172 & 4.251 & 2.433 \\
\hline-0.385 & -1.557 & 2.024 & 4.571 \\
\hline-0.580 & -2.472 & -1.101 & 5.177 \\
\hline 0.089 & -2.787 & -0.510 & 5.313 \\
\hline 0.057 & -1.116 & 2.465 & 5.012 \\
\hline 0.573 & -0.600 & 2.982 & 5.529 \\
\hline-0.818 & -3.645 & -0.672 & 0.669 \\
\hline-0.926 & -7.787 & -0.750 & 1.491 \\
\hline-0.407 & -2.621 & -0.575 & 3.754 \\
\hline-0.784 & -3.721 & -0.950 & 4.885 \\
\hline 1.798 & 0.429 & 4.763 & 6.721 \\
\hline-1.286 & -5.007 & -0.261 & 2.768 \\
\hline-1.237 & -2.868 & -1.460 & 0.199 \\
\hline
\end{tabular}


Further variables that we require are measures of the capital stock and gross output, and measures of average wages and the prices of output and intermediate inputs. All of these data are available directly from the WIOD database or can be easily calculated. ${ }^{10}$

\section{Results}

Before reporting results on the impact of offshoring on labour demand elasticties we report results on the evolution of the own price elasticity of labour demand for total employment. This allows for a comparison with results from Slaughter (2001) and Hijzen and Swaim (2010), amongst others, who also report such estimates for different samples and time periods. Hijzen and Swaim (2010) for example report an increase in the trend of the conditional wage elasticity of labour demand over the period 1985-2001.

Results on the estimated elasticities from the conditional labour demand equation are reported in Figure 3, which reports estimated elasticities for all industries, for manufacturing industries only and for services industries only. The estimated elasticities are expressed in absolute values and are based on three year averages to help smooth the estimates. The estimated elasticities for all industries match those of Hijzen and Swaim (2010) in the early period (i.e. the period of overlap in the two datasets) very closely and show a tendency to rise. The trend reverses however after 2000 until 2003 when we again see a sharp rise in estimated elasticities until 2006. In the final period the estimated elasticity is very similar to that reported in the first period, such that when considering the entire period there has been little change in the elasticity of labour demand.

When considering manufacturing and services separately we obtain much different patterns. In the case of manufacturing the elasticity is found to rise consistently until 2004 when it declines, with the value in 2009 being somewhat higher than that in the first period. Elasticities in the service sector follow closely those for all industries, albeit with a much larger decline in the estimated elasticities in the early 2000s. Overall however, the general tendency for rising elasticities found by Hijzen and Swaim (2010) for the period up to 2001 are not found for the more recent period.

In order to account for both substitution and scale effects we further report estimated elasticities from the unconditional labour-demand model in Figure 4, which thus estimates the total elasticity of demand. The patterns of the estimated elasticities are found to be fairly similar, though the size of the coefficients tends to be smaller in absolute value. This goes against the theory, but is similar to results found by both Slaughter (2001) and Hijzen and Swaim (2010).

10 Indices for the prices of output and intermediate inputs are available directly from the WIOD database, while average wages (for the total labour force and the labour force by skill level) are calculated using data on employment, total compensation to workers, and the share of total compensation to workers by skill-level. 
Figure 3

Trend in the conditional wage elasticity

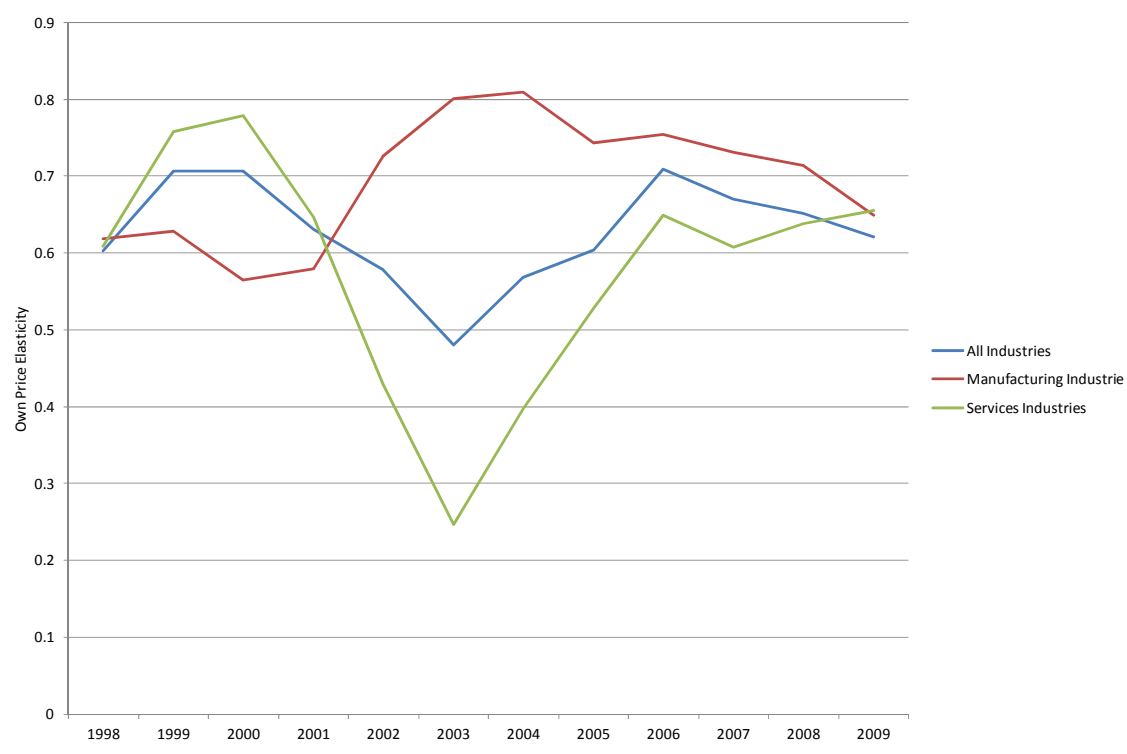

Figure 4

Trend in the unconditional wage elasticity

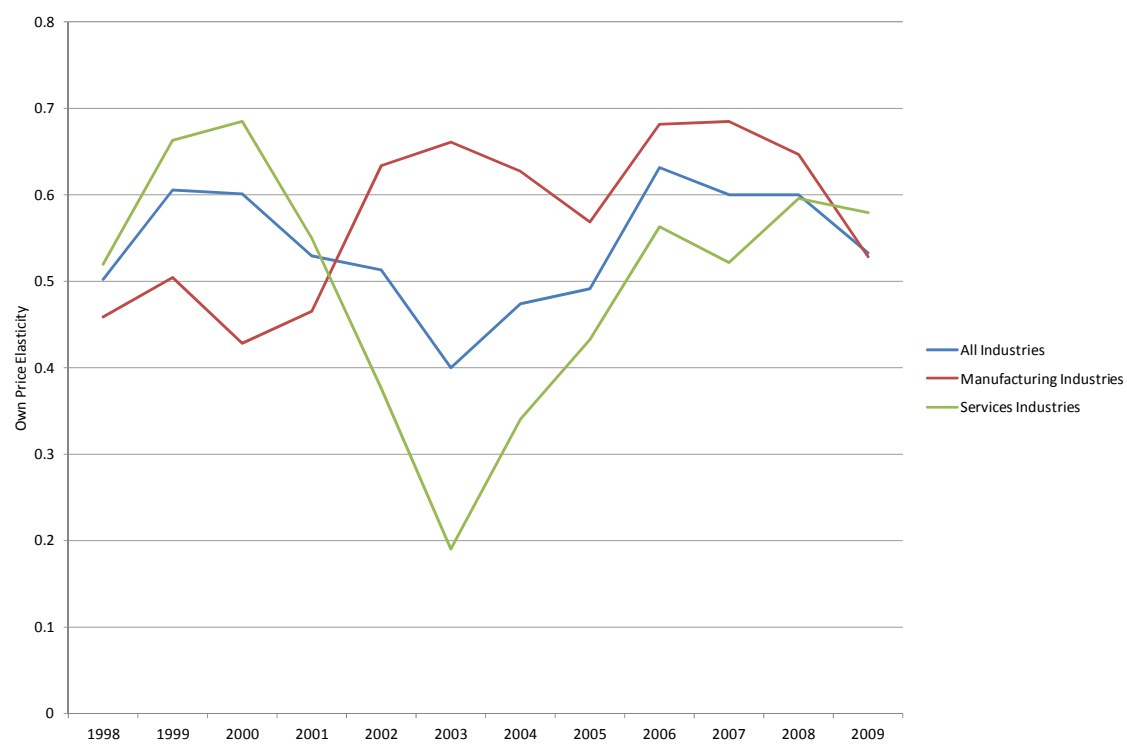

After estimating the own price elasticity of labour demand we now turn to our main results of interest, the impact of offshoring on labour elasticities. We proceed by estimating the conditional and unconditional labour demand models given by equations (1A) and (2A) to examine the impact of offshoring on labour elasticities. One issue in estimating these equations on the full sample of countries and industries is that the approach assumes that that the same labour demand function applies across industries. While this is a common assumption to make in the literature on offshoring (Feenstra and Hanson, 1999; Michaels et al., 2010) it is restrictive. To relax this assumption somewhat we report in addition to results 
for the full sample results for a number of different industry types, and in particular low-, medium- and high-tech manufacturing and low-, medium- and high-tech services industries. The allocation of industries into these categories is provided in Table A1 of the Appendix. The discussion of the results is split into two subsections. In the first subsection we report results for the full sample of countries and industries. Results are presented when including the narrow measure of offshoring only, when including both the narrow and broad offshoring measure, and when including the measures of manufacturing and services offshoring. In the second subsection we report results for the different industry types, which thus enables us to allow for different cost functions across industry types.

\subsection{Results for all countries and industries}

Table 2 reports results for both the conditional and unconditional labour demand models for total employment, and employment by education level (i.e. low, medium, and higheducation levels) when including the narrow measure of offshoring, which is thought to be closest to the essence of fragmentation. When considering the results for total employment in the conditional model we observe that the impact of the growth in the capital stock is negative, while that on output is positive (when significant), with the growth of wages having a negative impact on employment. The growth in the price of intermediates has a positive effect on total employment, but a negative effect on low-skilled employment. Turning to the coefficient on the narrow measure of offshoring we observe a negative coefficient that is significant. The coefficient indicates that a 1 percent increase in narrow offshoring lowers total employment by approximately 0.02 percent holding all else constant. This result supports previous research (e.g. Hizjen and Swaim, 2007 and 2010) indicating a negative substitution effect of offshoring. Results when considering the different education types in the conditional model are found to be fairly similar, with the negative effect of offshoring found consistently for the different education types. The coefficients for low- and mediumeducated workers are found to be similar and relatively large, while that on high-educated workers is negative, but not significant.

The conditional labour demand model accounts for substitution effects only and not the overall impact of offshoring (i.e. substitution plus scale effect). As such, we turn to the results from the unconditional labour demand model, which are reported in the final four columns of Table 2. Here we observe positive and significant coefficients on the capital growth variable and on the growth of intermediate input prices. Coefficients on wages are again found to be negative and significant, but are smaller in absolute value than those from the conditional labour-demand model, which as noted above is inconsistent with theory but not with other existing empirical results. Concentrating on the offshoring measure we find coefficients on the narrow offshoring measure that tend to be insignificant, both for total employment and employment by the different education types. The exception to this is the coefficient for high-educated employment, which is found to be positive and significant. 
As such, the results for all industries would tend to support the view that (with the exception of high-educated workers) there is no significant overall impact of offshoring on labour demand, with the negative substitution effect found in the conditional model being offset by a positive scale effect.

Table 3 adds to the results in Table 2 by including the broad measure of offshoring. Given the similarity of the coefficients on the existing variables to those presented above we turn immediately to the results on the two offshoring measures. In the conditional labour demand model we continue to find negative and significant coefficients on the narrow offshoring variable for all employment types except high-educated labour. Coefficients on the broad measure of offshoring are also consistently negative and significant, with the exception of high-educated labour. The estimated elasticity of narrow offshoring is somewhat reduced when including broad offshoring, with a 1 percent increase in narrow offshoring lowering total employment by around 0.01 percent. The elasticity for broad offshoring is found to be larger than this, with a 1 percent increase in broad offshoring associated with a 0.05 percent decline in employment. The elasticities tend to be largest for low-educated labour in the case of narrow offshoring and for medium-educated labour in the case of broad offshoring. Results from the unconditional labour demand model indicate that there tends to be no significant effect of narrow offshoring on either total employment or employment by skill-level. Once again therefore the results for all industries would seem to suggest that the overall effect of narrow offshoring on employment is negligible, with the negative substitution effect offset by a positive scale effect. In the case of broad offshoring results tend to indicate a positive effect of offshoring, both for total employment and for employment by education level. Coefficients tend to be particularly large for high- and loweducated labour. Such results indicate that broad offshoring may have an overall positive impact on employment of some kinds of labour.

The results in Table 4 shift away from the focus on narrow and broad offshoring to distinguish between manufacturing and services offshoring. Concentrating on the two offshoring measures we find when looking at the conditional labour demand results (Columns 1-4) negative and significant coefficients on the measure of manufacturing offshoring, the effects of which are largest when considering medium-skilled employment, and coefficients on services offshoring that are insignificant except in the case of high-skilled employment where the coefficient is positive and significant. When considering the unconditional labour demand model (Columns 5-8) we find a positive effect of manufacturing offshoring and a negative effect of service offshoring. The positive effect of manufacturing offshoring is driven by its impact on high- and low-educated labour, while the negative effect of service offshoring is due to significant effects on low- and medium-educated employment. 
Table 2

Narrow offshoring for all industries

\begin{tabular}{|c|c|c|c|c|c|c|c|c|}
\hline & $\begin{array}{c}(1) \\
E M P_{-} A L L\end{array}$ & $\begin{array}{l}\text { Conditione } \\
\text { (2) } \\
E M P \_L S \\
\end{array}$ & $\begin{array}{l}\text { Model } \\
\text { (3) } \\
E M P \_M S \\
\end{array}$ & $\begin{array}{c}(4) \\
E M P_{-} H S\end{array}$ & $\begin{array}{c}(5) \\
E M P \_A L L\end{array}$ & $\begin{array}{c}\text { Unconditic } \\
\text { (6) } \\
E M P_{-} L S\end{array}$ & $\begin{array}{c}\text { Ial Model } \\
(7) \\
E M P_{-} M S \\
\end{array}$ & $\begin{array}{c}(8) \\
E M P_{-} H S\end{array}$ \\
\hline$\Delta w_{A L L}$ & $\begin{array}{c}-0.558^{\star \star \star} \\
(0.0357)\end{array}$ & & & & $\begin{array}{l}-0.393^{\star * \star} \\
(0.0339)\end{array}$ & & & \\
\hline$\Delta w_{L S}$ & & $\begin{array}{l}-0.323^{\star \star \star} \\
(0.0287)\end{array}$ & & & & $\begin{array}{l}-0.233^{* * *} \\
(0.0273)\end{array}$ & & \\
\hline$\Delta w_{M S}$ & & & $\begin{array}{l}-0.454^{\star \star \star} \\
(0.0322)\end{array}$ & & & & $\begin{array}{l}-0.330 * \star * \\
(0.0308)\end{array}$ & \\
\hline$\Delta w_{H S}$ & & & & $\begin{array}{l}-0.428^{\star * \star} \\
(0.0277)\end{array}$ & & & & $\begin{array}{c}-0.323^{\star \star \star} \\
(0.0260)\end{array}$ \\
\hline$\Delta w_{I I}$ & $\begin{array}{c}0.0463^{\star \star \star} \\
(0.0164)\end{array}$ & $\begin{array}{l}-0.0318^{*} \\
(0.0173)\end{array}$ & $\begin{array}{l}0.00635 \\
(0.0165)\end{array}$ & $\begin{array}{l}-0.0286 \\
(0.0182)\end{array}$ & $\begin{array}{l}0.270 \star \star \star \\
(0.0287)\end{array}$ & $\begin{array}{l}0.182^{\star \star \star} \\
(0.0233)\end{array}$ & $\begin{array}{l}0.213^{\star \star \star} \\
(0.0257)\end{array}$ & $\begin{array}{l}0.183^{\star \star \star} \\
(0.0239)\end{array}$ \\
\hline$\Delta K$ & $\begin{array}{c}-0.0683^{* * *} \\
(0.00505)\end{array}$ & $\begin{array}{c}-0.0474^{\star * *} \\
(0.00505)\end{array}$ & $\begin{array}{l}-0.0550 \text { *** } \\
(0.00507)\end{array}$ & $\begin{array}{l}-0.0536^{\star \star *} \\
(0.00577)\end{array}$ & $\begin{array}{l}0.0145^{\star * *} \\
(0.00377)\end{array}$ & $\begin{array}{l}0.0201 * * * \\
(0.00444)\end{array}$ & $\begin{array}{l}0.0159 * * * \\
(0.00401)\end{array}$ & $\begin{array}{l}0.0147^{* * *} \\
(0.00498)\end{array}$ \\
\hline$\Delta Y$ & $\begin{array}{l}0.549 \star \star \star \\
(0.0254)\end{array}$ & $\begin{array}{l}0.449 * \star \star \\
(0.0242)\end{array}$ & $\begin{array}{l}0.476 * \star \star \\
(0.0249)\end{array}$ & $\begin{array}{l}0.460 * \star \star \\
(0.0242)\end{array}$ & & & & \\
\hline$\Delta I I M^{N}$ & $\begin{array}{l}-0.0171 * \star * \\
(0.00269)\end{array}$ & $\begin{array}{c}-0.0133^{\star * *} \\
(0.00409)\end{array}$ & $\begin{array}{l}-0.0140 * * * \\
(0.00326)\end{array}$ & $\begin{array}{l}-0.00675 \\
(0.00440)\end{array}$ & $\begin{array}{c}0.00299 \\
(0.00278)\end{array}$ & $\begin{array}{c}0.00339 \\
(0.00423)\end{array}$ & $\begin{array}{c}0.00316 \\
(0.00337)\end{array}$ & $\begin{array}{l}0.00988 * * \\
(0.00474)\end{array}$ \\
\hline $\begin{array}{l}\text { Observations } \\
\text { R-squared } \\
\text { F-test }\end{array}$ & $\begin{array}{c}15,270 \\
0.567 \\
16.20 \star \star \star \\
\end{array}$ & $\begin{array}{c}15,270 \\
0.220 \\
3.49 \star \star \star\end{array}$ & $\begin{array}{c}15,270 \\
0.383 \\
7.69 \star \star \star\end{array}$ & $\begin{array}{c}15,270 \\
0.218 \\
3.44^{\star \star \star}\end{array}$ & $\begin{array}{c}15,270 \\
0.366 \\
7.14^{\star \star \star} \\
\end{array}$ & $\begin{array}{c}15,270 \\
0.150 \\
2.19 \star \star \star\end{array}$ & $\begin{array}{c}15,270 \\
0.268 \\
4.52^{\star \star \star}\end{array}$ & $\begin{array}{c}15,270 \\
0.159 \\
2.34^{\star \star \star}\end{array}$ \\
\hline
\end{tabular}

Robust standard errors in parentheses, ${ }^{* \star} p<0.01,{ }^{* \star} p<0.05,{ }^{*} p<0.1$

Table 3

Narrow and broad offshoring for all industries

\begin{tabular}{|c|c|c|c|c|c|c|c|c|}
\hline & $\begin{array}{c}(1) \\
E M P \_A L L\end{array}$ & $\begin{array}{l}\text { Conditio } \\
\text { (2) } \\
E M P_{-} L S \\
\end{array}$ & $\begin{array}{l}\text { al Model } \\
\text { (3) } \\
E M P_{-} M S \\
\end{array}$ & $\begin{array}{c}(4) \\
E M P \_H S\end{array}$ & $\begin{array}{c}(5) \\
E M P \_A L L\end{array}$ & $\begin{array}{l}\text { Unconditi } \\
\text { (6) } \\
E M P \_L S\end{array}$ & $\begin{array}{c}\text { nal Model } \\
\text { (7) } \\
E M P_{-} M S \\
\end{array}$ & $\begin{array}{c}\text { (8) } \\
\text { EMP_HS }\end{array}$ \\
\hline$\Delta w_{A L L}$ & $\begin{array}{c}-0.565^{\star \star \star} \\
(0.0362)\end{array}$ & & & & $\begin{array}{c}-0.393^{\star * *} \\
(0.0338)\end{array}$ & & & \\
\hline$\Delta w_{L S}$ & & $\begin{array}{c}-0.325^{\star \star \star} \\
(0.0288)\end{array}$ & & & & $\begin{array}{c}-0.233^{\star * \star} \\
(0.0272)\end{array}$ & & \\
\hline$\Delta w_{M S}$ & & & $\begin{array}{l}-0.459 * \star \star \\
(0.0324)\end{array}$ & & & & $\begin{array}{l}-0.330 * \star \star \\
(0.0307)\end{array}$ & \\
\hline$\Delta w_{H S}$ & & & & $\begin{array}{c}-0.430 * \star \star \\
(0.0278)\end{array}$ & & & & $\begin{array}{c}-0.323^{\star \star *} \\
(0.0258)\end{array}$ \\
\hline$\Delta w_{I I}$ & $\begin{array}{c}0.0446^{\star * \star} \\
(0.0164)\end{array}$ & $\begin{array}{l}-0.0329 * \\
(0.0174)\end{array}$ & $\begin{array}{l}0.00435 \\
(0.0165)\end{array}$ & $\begin{array}{c}-0.0292 \\
(0.0182)\end{array}$ & $\begin{array}{l}0.267^{\star \star *} \\
(0.0285)\end{array}$ & $\begin{array}{l}0.177^{\star * *} \\
(0.0230)\end{array}$ & $\begin{array}{l}0.211^{\star \star *} \\
(0.0254)\end{array}$ & $\begin{array}{l}0.177^{\star \star \star} \\
(0.0236)\end{array}$ \\
\hline$\Delta K$ & $\begin{array}{c}-0.0773^{* * *} \\
(0.00570)\end{array}$ & $\begin{array}{c}-0.0511^{\star * *} \\
(0.00530)\end{array}$ & $\begin{array}{l}-0.0626^{\star \star *} \\
(0.00552)\end{array}$ & $\begin{array}{l}-0.0557^{* * *} \\
(0.00604)\end{array}$ & $\begin{array}{l}0.0164 * \star * \\
(0.00384)\end{array}$ & $\begin{array}{l}0.0236^{\star * *} \\
(0.00454)\end{array}$ & $\begin{array}{l}0.0176^{\star * *} \\
(0.00408)\end{array}$ & $\begin{array}{l}0.0193^{* * *} \\
(0.00510)\end{array}$ \\
\hline$\Delta Y$ & $\begin{array}{l}0.572^{\star * *} \\
(0.0267)\end{array}$ & $\begin{array}{l}0.458^{\star \star *} \\
(0.0249)\end{array}$ & $\begin{array}{l}0.495^{\star * \star} \\
(0.0258)\end{array}$ & $\begin{array}{l}0.466^{\star \star \star} \\
(0.0250)\end{array}$ & & & & \\
\hline$\Delta I I M^{N}$ & $\begin{array}{c}-0.0102^{* * *} \\
(0.00244)\end{array}$ & $\begin{array}{l}-0.0104^{\star *} \\
(0.00420)\end{array}$ & $\begin{array}{c}-0.00816^{\star \star \star} \\
(0.00315)\end{array}$ & $\begin{array}{l}-0.00508 \\
(0.00453)\end{array}$ & $\begin{array}{l}0.000324 \\
(0.00270)\end{array}$ & $\begin{array}{l}-0.00156 \\
(0.00429)\end{array}$ & $\begin{array}{l}0.000872 \\
(0.00336)\end{array}$ & $\begin{array}{c}0.00348 \\
(0.00470)\end{array}$ \\
\hline$\Delta I I M^{B}$ & $\begin{array}{c}-0.0494^{\star * *} \\
(0.00666)\end{array}$ & $\begin{array}{l}-0.0211^{\star \star} \\
(0.00896)\end{array}$ & $\begin{array}{l}-0.0421^{\star * *} \\
(0.00728)\end{array}$ & $\begin{array}{c}-0.0119 \\
(0.00957)\end{array}$ & $\begin{array}{l}0.0172^{\star \star \star} \\
(0.00631)\end{array}$ & $\begin{array}{l}0.0318^{\star \star *} \\
(0.00883)\end{array}$ & $\begin{array}{c}0.0147^{\star \star} \\
(0.00720)\end{array}$ & $\begin{array}{c}0.0412^{\star * *} \\
(0.0100)\end{array}$ \\
\hline $\begin{array}{l}\text { Observations } \\
\text { R-squared } \\
\text { F-test }\end{array}$ & $\begin{array}{c}15,270 \\
0.573 \\
16.60^{\star \star \star}\end{array}$ & $\begin{array}{c}15,270 \\
0.221 \\
3.50 \star \star \star\end{array}$ & $\begin{array}{c}15,270 \\
0.387 \\
7.79 \star \star \star\end{array}$ & $\begin{array}{c}15,270 \\
0.218 \\
3.44^{\star \star \star}\end{array}$ & $\begin{array}{c}15,270 \\
0.366 \\
7.16^{\star \star \star}\end{array}$ & $\begin{array}{c}15,270 \\
0.151 \\
2.21^{\star \star \star}\end{array}$ & $\begin{array}{c}15,270 \\
0.268 \\
4.53^{\star \star \star}\end{array}$ & $\begin{array}{c}15,270 \\
0.161 \\
2.37^{\star \star \star}\end{array}$ \\
\hline
\end{tabular}

Robust standard errors in parentheses, ${ }^{\star \star *} p<0.01,{ }^{\star \star} p<0.05,{ }^{*} p<0.1$ 
Manufacturing and services offshoring for all industries

\begin{tabular}{|c|c|c|c|c|c|c|c|c|}
\hline & \multicolumn{4}{|c|}{ Conditional Model } & \multicolumn{4}{|c|}{ Unconditional Model } \\
\hline & $\begin{array}{c}(1) \\
E M P_{-} A L L\end{array}$ & $\begin{array}{c}(2) \\
E M P_{-} L S\end{array}$ & $\begin{array}{c}(3) \\
E M P \_M S\end{array}$ & $\begin{array}{c}(4) \\
E M P \_H S\end{array}$ & $\begin{array}{c}(5) \\
E M P_{-} A L L\end{array}$ & $\begin{array}{c}(6) \\
E M P_{-} L S\end{array}$ & $\begin{array}{c}(7) \\
E M P_{-} M S\end{array}$ & $\begin{array}{c}\text { (8) } \\
E M P \_H S\end{array}$ \\
\hline$\Delta w_{A L L}$ & $\begin{array}{l}-0.563^{\star * *} \\
(0.0357)\end{array}$ & & & & $\begin{array}{c}-0.391^{* * *} \\
(0.0335)\end{array}$ & & & \\
\hline$\Delta w_{L S}$ & & $\begin{array}{c}-0.324^{\star \star *} \\
(0.0285)\end{array}$ & & & & $\begin{array}{c}-0.233^{\star \star *} \\
(0.0269)\end{array}$ & & \\
\hline$\Delta w_{M S}$ & & & $\begin{array}{c}-0.458^{\star * \star} \\
(0.0320)\end{array}$ & & & & $\begin{array}{c}-0.329^{\star * *} \\
(0.0304)\end{array}$ & \\
\hline$\Delta w_{H S}$ & & & & $\begin{array}{l}-0.432^{\star \star *} \\
(0.0276)\end{array}$ & & & & $\begin{array}{l}-0.322^{\star \star *} \\
(0.0257)\end{array}$ \\
\hline$\Delta w_{I I}$ & $\begin{array}{c}0.0429 * * * \\
(0.0160)\end{array}$ & $\begin{array}{c}-0.0340 * * \\
(0.0171)\end{array}$ & $\begin{array}{l}0.00248 \\
(0.0162)\end{array}$ & $\begin{array}{l}-0.0328^{*} \\
(0.0179)\end{array}$ & $\begin{array}{l}0.271 * \star \star \\
(0.0286)\end{array}$ & $\begin{array}{l}0.180^{* * *} \\
(0.0232)\end{array}$ & $\begin{array}{l}0.215^{\star \star \star} \\
(0.0255)\end{array}$ & $\begin{array}{l}0.180^{\star * *} \\
(0.0236)\end{array}$ \\
\hline$\Delta K$ & $\begin{array}{c}-0.0764^{\star \star \star} \\
(0.00576)\end{array}$ & $\begin{array}{c}-0.0504^{\star * *} \\
(0.00548)\end{array}$ & $\begin{array}{l}-0.0625^{\star \star *} \\
(0.00564)\end{array}$ & $\begin{array}{l}-0.0578^{* * *} \\
(0.00620)\end{array}$ & $\begin{array}{l}0.0158^{\star * *} \\
(0.00390)\end{array}$ & $\begin{array}{l}0.0228^{\star * *} \\
(0.00456)\end{array}$ & $\begin{array}{l}0.0166^{\star * *} \\
(0.00413)\end{array}$ & $\begin{array}{l}0.0173^{\star \star *} \\
(0.00512)\end{array}$ \\
\hline$\Delta Y$ & $\begin{array}{l}0.572^{\star \star \star} \\
(0.0269)\end{array}$ & $\begin{array}{l}0.457^{\star \star \star} \\
(0.0253)\end{array}$ & $\begin{array}{l}0.496^{\star \star *} \\
(0.0260)\end{array}$ & $\begin{array}{l}0.473^{\star \star \star} \\
(0.0251)\end{array}$ & $\begin{array}{c}0.0133^{*} \\
(0.00704)\end{array}$ & $\begin{array}{l}0.0266^{\star \star *} \\
(0.00870)\end{array}$ & $\begin{array}{c}0.00929 \\
(0.00757)\end{array}$ & $\begin{array}{l}0.0314^{\star \star *} \\
(0.00963)\end{array}$ \\
\hline$\Delta I I M^{M}$ & $\begin{array}{l}-0.0523^{* \star *} \\
(0.00757)\end{array}$ & $\begin{array}{c}-0.0250^{\star \star *} \\
(0.00892)\end{array}$ & $\begin{array}{l}-0.0467^{* * *} \\
(0.00783)\end{array}$ & $\begin{array}{l}-0.0227^{\star *} \\
(0.00952)\end{array}$ & & & & \\
\hline$\Delta I I M^{S}$ & $\begin{array}{c}0.00117 \\
(0.00443)\end{array}$ & $\begin{array}{l}-0.00601 \\
(0.00694)\end{array}$ & $\begin{array}{r}-0.000480 \\
(0.00532)\end{array}$ & $\begin{array}{c}0.0158^{\star *} \\
(0.00768)\end{array}$ & $\begin{array}{c}-0.0130 * \star \star \\
(0.00501)\end{array}$ & $\begin{array}{l}-0.0159 * * \\
(0.00721)\end{array}$ & $\begin{array}{l}-0.0123^{\star *} \\
(0.00567)\end{array}$ & $\begin{array}{c}0.00284 \\
(0.00788)\end{array}$ \\
\hline Observations & 15,377 & 15,377 & 15,377 & 15,377 & 15,377 & 15,377 & 15,377 & 15,377 \\
\hline R-squared & 0.571 & 0.221 & 0.387 & 0.219 & 0.366 & 0.152 & 0.268 & 0.160 \\
\hline F-test & $16.60^{\star \star \star *}$ & $3.53^{\star \star \star}$ & $7.87^{\star \star \star}$ & $3.49 * \star \star$ & $7.18^{\star \star \star}$ & $2.24^{\star \star \star}$ & $4.56^{\star \star \star}$ & $2.38^{\star \star \star}$ \\
\hline
\end{tabular}

Robust standard errors in parentheses, ${ }^{* \star} p<0.01,{ }^{* \star} p<0.05,{ }^{*} p<0.1$

\subsection{Results by industry type}

The results above suggest that narrow offshoring has an overall neutral effect on employment in our sample of countries, while broad offshoring may actually increase employment (particularly of low- and high-educated labour). The oft-cited negative effects of offshoring on labour markets do not seem to find strong support in our results therefore, despite some evidence of a negative employment of service offshoring. In this subsection we examine whether the results found for the full sample of countries and industries also holds when we allow for differences across industry types, and in particular for low-, medium- and hightech manufacturing and services industries.

Table 5 reports the coefficients on the narrow and broad offshoring variables only for the six different industry types in the case of total employment and for employment by education level. ${ }^{11}$ Considering the results from the conditional model we find when estimating the model separately for each of the industry types a variety of coefficients on the narrow offshoring measure. When considering manufacturing industries we obtain coefficients that are negative and significant for total employment and for the three employment types in the case of low- and high-tech industries. Elasticities are found to be relatively large in the case of high-tech manufacturing industries. In all manufacturing industries the elasticity is found

11 We choose not to report results when including the measure of narrow offshoring only as the results are very similar to those when including the broad measure also. Such results are available upon request however. 
to be largest in absolute value for high-educated employment, usually closely followed by low-skilled employment. For the service industries we tend to obtain coefficients that are much smaller and that tend to be insignificant for both total employment and employment by skill level. Only in the case of medium-tech services do we find a significant negative impact of offshoring on employment, which tends to work by affecting low- and medium-educated employment. Coefficients on the narrow offshoring measure in the unconditional model are in all cases insignificant. As such, the results are consistent with those presented for all industries and indicate that overall there is no evidence of a (significant) negative effect of narrow offshoring on either total employment or on employment by education type.

For broad offshoring we tend to find negative effects of offshoring on total employment for all manufacturing industries. The negative effects of offshoring tend to be observed for all education types, with the effect often found to be largest for medium-educated workers. In the case of services industries there are few significant coefficients, though broad offshoring tends to have a negative impact on total employment in medium- and high-tech industries. When we turn to the results from the unconditional model we again find little evidence of an overall negative effect of broad offshoring on employment in these different industries. In particular, we find only one significantly negative coefficient (for medium-educated employment in medium-tech industries), with positive coefficients found for low-educated labour in low- and medium-tech industries and for high-educated employment in mediumand high-tech manufacturing and in low- and medium-tech services industries.

Finally, in Table 6 we report coefficients on the manufacturing and services offshoring measures for the different industry types. In the conditional labour demand model we find negative effects of manufacturing offshoring in all manufacturing industries, with the effects tending to be largest in high-tech, followed by low-tech industries. The effects of manufacturing offshoring are found to impact more strongly on high-skilled employment in low- and high-tech industries and on medium-skilled employment in the medium-tech industries. For services industries we find negative effects of manufacturing offshoring which tend to be strongest for low- and medium-educated workers in low- and medium-tech industries and for high-educated workers in high-tech industries. For services offshoring we find few significant effects on employment in manufacturing industries, with the exception of a positive coefficient found in the case of low-tech manufacturing. For service industries however we find negative effects of service offshoring on low- and medium-educated employment in low-tech services and a positive effect in high-tech services, which is driven by positive effects for high- and low-educated labour.

Results from the unconditional model indicate that manufacturing offshoring impacts positively upon employment in high-tech manufacturing and low-tech services, with low- and high-educated employment found to react positively to manufacturing offshoring. Service 
Table 5

Narrow and broad offshoring for different industry types

\begin{tabular}{|c|c|c|c|c|c|c|c|c|}
\hline \multirow[b]{3}{*}{ VARIABLES } & \multicolumn{4}{|c|}{ Conditional Model } & \multicolumn{4}{|c|}{ Unconditional Model } \\
\hline & (1) & (2) & (3) & (4) & (5) & (6) & (7) & (8) \\
\hline & $E M P_{-} A L L$ & $E M P \_L S$ & $E M P \_M S$ & $E M P_{-} H S$ & $E M P \_A L L$ & $E M P \_L S$ & $E M P \_M S$ & $E M P \_H S$ \\
\hline \multicolumn{9}{|l|}{ NARROW OFFSHORING } \\
\hline \multirow[t]{2}{*}{ Manufacturing - Low } & $-0.0228 * \star \star$ & $-0.0200^{\star \star \star}$ & $-0.0172^{\star \star \star}$ & $-0.0265^{\star \star \star}$ & -0.00157 & -0.000380 & 0.000491 & -0.00865 \\
\hline & $(0.00624)$ & $(0.00605)$ & $(0.00609)$ & $(0.00948)$ & $(0.00486)$ & $(0.00610)$ & $(0.00522)$ & (0.00938) \\
\hline \multirow[t]{2}{*}{ Manufacturing - Medium } & -0.0112 & -0.0108 & 0.00355 & -0.0413 & 0.00502 & 0.00311 & 0.0163 & -0.0270 \\
\hline & $(0.00835)$ & $(0.0140)$ & $(0.0150)$ & $(0.0265)$ & $(0.00921)$ & $(0.0148)$ & $(0.0151)$ & $(0.0262)$ \\
\hline \multirow[t]{2}{*}{ Manufacturing - High } & $-0.0583^{\star * \star}$ & $-0.0340 *$ & $-0.0430 * * \star$ & $-0.0487^{* \star}$ & 0.0177 & 0.0310 & 0.0171 & 0.0166 \\
\hline & $(0.0139)$ & $(0.0174)$ & (0.0163) & $(0.0192)$ & $(0.0167)$ & $(0.0190)$ & $(0.0178)$ & $(0.0218)$ \\
\hline \multirow[t]{2}{*}{ Services - Low } & 0.000215 & -0.00915 & -0.00376 & $0.0246 * \star$ & -0.00755 & -0.0145 & -0.0110 & 0.0196 \\
\hline & $(0.00567)$ & $(0.0101)$ & $(0.00647)$ & $(0.0125)$ & $(0.00660)$ & (0.00993) & (0.00718) & $(0.0126)$ \\
\hline \multirow[t]{2}{*}{ Services - Medium } & $-0.00967^{* *}$ & $-0.0131^{*}$ & $-0.00917^{*}$ & -0.00460 & -0.00297 & -0.00778 & -0.00302 & 0.00106 \\
\hline & $(0.00389)$ & $(0.00739)$ & $(0.00514)$ & $(0.00647)$ & $(0.00429)$ & $(0.00745)$ & $(0.00546)$ & $(0.00662)$ \\
\hline \multirow[t]{2}{*}{ Services - High } & 0.00185 & 0.0130 & 0.00472 & 0.00851 & 0.00910 & 0.0162 & 0.0106 & 0.0143 \\
\hline & $(0.00714)$ & $(0.00944)$ & $(0.00770)$ & $(0.00858)$ & $(0.00723)$ & (0.00988) & $(0.00767)$ & $(0.00995)$ \\
\hline \multicolumn{9}{|l|}{ BROAD OFFSHORING } \\
\hline \multirow[t]{2}{*}{ Manufacturing - Low } & $-0.0840 * * \star$ & -0.0559 *** & $-0.0575^{\star \star \star}$ & $-0.0535^{\star \star}$ & 0.0121 & $0.0283^{*}$ & 0.0244 & 0.0208 \\
\hline & $(0.0191)$ & $(0.0205)$ & (0.0201) & $(0.0227)$ & $(0.0147)$ & $(0.0160)$ & $(0.0154)$ & $(0.0273)$ \\
\hline \multirow[t]{2}{*}{ Manufacturing - Medium } & $-0.0418^{\star \star \star}$ & -0.00268 & $-0.0732^{* \star \star}$ & 0.0545 & 0.0112 & $0.0447^{* \star}$ & $-0.0350^{*}$ & $0.104^{\star \star}$ \\
\hline & $(0.0152)$ & $(0.0254)$ & (0.0219) & $(0.0399)$ & $(0.0142)$ & $(0.0225)$ & $(0.0210)$ & $(0.0410)$ \\
\hline \multirow[t]{2}{*}{ Manufacturing - High } & $-0.0561^{* \star \star}$ & $-0.0462^{\star \star \star}$ & $-0.0406^{\star \star \star}$ & $-0.0373^{\star \star}$ & 0.0240 & 0.0240 & 0.0244 & $0.0341^{*}$ \\
\hline & $(0.0123)$ & $(0.0161)$ & $(0.0138)$ & $(0.0181)$ & $(0.0166)$ & $(0.0190)$ & $(0.0178)$ & $(0.0206)$ \\
\hline \multirow[t]{2}{*}{ Services - Low } & -0.0345 & -0.0168 & -0.0354 & 0.0343 & $0.0458 * *$ & 0.0530 & 0.0359 & $0.0793^{\star *}$ \\
\hline & $(0.0211)$ & $(0.0322)$ & $(0.0247)$ & $(0.0342)$ & $(0.0228)$ & $(0.0327)$ & $(0.0251)$ & $(0.0325)$ \\
\hline \multirow[t]{2}{*}{ Services - Medium } & $-0.0360 * * *$ & -0.0144 & $-0.0304^{* * *}$ & -0.00249 & 0.0123 & 0.0200 & 0.0137 & $0.0348 * *$ \\
\hline & $(0.0108)$ & $(0.0153)$ & $(0.0115)$ & $(0.0155)$ & $(0.0108)$ & $(0.0162)$ & $(0.0122)$ & $(0.0161)$ \\
\hline \multirow[t]{2}{*}{ Services - High } & $-0.0383^{*}$ & 0.0156 & -0.0327 & -0.0279 & 0.00950 & 0.0411 & 0.00847 & 0.0174 \\
\hline & $(0.0210)$ & $(0.0288)$ & $(0.0231)$ & $(0.0255)$ & $(0.0210)$ & $(0.0286)$ & $(0.0234)$ & $(0.0268)$ \\
\hline
\end{tabular}

Standard errors in parentheses, ${ }^{* \star} p<0.01,{ }^{\star *} p<0.05,{ }^{*} p<0.1$

Table 6

Manufacturing and services offshoring for different industry types

\begin{tabular}{|c|c|c|c|c|c|c|c|c|}
\hline & $\begin{array}{c}(1) \\
E M P \_A L L\end{array}$ & $\begin{array}{c}\text { Conditio } \\
\text { (2) } \\
E M P_{-} L S\end{array}$ & $\begin{array}{c}\text { רal Model } \\
\text { (3) } \\
E M P_{-} M S\end{array}$ & $\begin{array}{c}(4) \\
E M P_{-} H S\end{array}$ & $\begin{array}{c}(5) \\
E M P \_A L L\end{array}$ & $\begin{array}{l}\text { Uncondit } \\
\text { (6) } \\
E M P_{-} L S\end{array}$ & $\begin{array}{c}\text { nal Model } \\
\text { (7) } \\
E M P_{-} M S\end{array}$ & $\begin{array}{c}(8) \\
E M P \_H S\end{array}$ \\
\hline \multicolumn{9}{|l|}{ MANUFACTURING } \\
\hline Manufacturing - Low & $\begin{array}{c}-0.126 * \star \star \\
(0.0198)\end{array}$ & $\begin{array}{c}-0.0780 \star \star \star \\
(0.0222)\end{array}$ & $\begin{array}{c}-0.0989 * \star * \\
(0.0221)\end{array}$ & $\begin{array}{c}-0.101^{\star \star *} \\
(0.0252)\end{array}$ & $\begin{array}{c}0.0157 \\
(0.0168)\end{array}$ & $\begin{array}{l}0.0441^{\star *} \\
(0.0181)\end{array}$ & $\begin{array}{c}0.0240 \\
(0.0174)\end{array}$ & $\begin{array}{c}0.0105 \\
(0.0262)\end{array}$ \\
\hline Manufacturing - Medium & $\begin{array}{c}-0.0412^{\star *} \\
(0.0169)\end{array}$ & $\begin{array}{l}0.00132 \\
(0.0259)\end{array}$ & $\begin{array}{c}-0.0648^{\star \star \star} \\
(0.0225)\end{array}$ & $\begin{array}{c}0.0329 \\
(0.0326)\end{array}$ & $\begin{array}{c}0.0236 \\
(0.0150)\end{array}$ & $\begin{array}{c}0.0586 * \star * \\
(0.0219)\end{array}$ & $\begin{array}{l}-0.0177 \\
(0.0211)\end{array}$ & $\begin{array}{r}0.0918^{\star \star \star} \\
(0.0322)\end{array}$ \\
\hline Manufacturing - High & $\begin{array}{l}-0.109 * * * \\
(0.0128)\end{array}$ & $\begin{array}{c}-0.0660^{* \star *} \\
(0.0191)\end{array}$ & $\begin{array}{c}-0.0844^{* * *} \\
(0.0148)\end{array}$ & $\begin{array}{c}-0.0834^{\star * *} \\
(0.0176)\end{array}$ & $\begin{array}{l}0.0521^{* * *} \\
(0.0137)\end{array}$ & $\begin{array}{c}0.0715^{\star * *} \\
(0.0170)\end{array}$ & $\begin{array}{l}0.0462^{* \star *} \\
(0.0143)\end{array}$ & $\begin{array}{r}0.0584^{* * *} \\
(0.0191)\end{array}$ \\
\hline Services - Low & $\begin{array}{l}-0.0317^{*} \\
(0.0165)\end{array}$ & $\begin{array}{l}-0.0184 \\
(0.0237)\end{array}$ & $\begin{array}{l}-0.0357^{\star} \\
(0.0185)\end{array}$ & $\begin{array}{c}0.0399 \\
(0.0271)\end{array}$ & $\begin{array}{l}0.0417^{\star \star} \\
(0.0171)\end{array}$ & $\begin{array}{l}0.0470^{\star} \\
(0.0242)\end{array}$ & $\begin{array}{c}0.0283 \\
(0.0184)\end{array}$ & $\begin{array}{r}0.0802^{* \star *} \\
(0.0257)\end{array}$ \\
\hline Services - Medium & $\begin{array}{c}-0.0346^{\star * *} \\
(0.0117)\end{array}$ & $\begin{array}{l}-0.0234^{*} \\
(0.0139)\end{array}$ & $\begin{array}{c}-0.0319 * * * \\
(0.0120)\end{array}$ & $\begin{array}{l}-0.0112 \\
(0.0147)\end{array}$ & $\begin{array}{l}0.00206 \\
(0.0116)\end{array}$ & $\begin{array}{l}0.00258 \\
(0.0141)\end{array}$ & $\begin{array}{l}0.00158 \\
(0.0123)\end{array}$ & $\begin{array}{c}0.0191 \\
(0.0153)\end{array}$ \\
\hline Services - High & $\begin{array}{c}-0.0465^{\star \star *} \\
(0.0177)\end{array}$ & $\begin{array}{l}0.00887 \\
(0.0230)\end{array}$ & $\begin{array}{l}-0.0356^{*} \\
(0.0185)\end{array}$ & $\begin{array}{c}-0.0483^{\star \star} \\
(0.0240)\end{array}$ & $\begin{array}{c}-0.00216 \\
(0.0176)\end{array}$ & $\begin{array}{c}0.0315 \\
(0.0229)\end{array}$ & $\begin{array}{l}0.00140 \\
(0.0190)\end{array}$ & $\begin{array}{r}-0.00339 \\
(0.0243)\end{array}$ \\
\hline SERVICE OFFSHORING & & & & & & & & \\
\hline Manufacturing - Low & $\begin{array}{l}0.0281^{\star \star \star} \\
(0.00950)\end{array}$ & $\begin{array}{c}0.0125 \\
(0.0115)\end{array}$ & $\begin{array}{c}0.0391 * * * \\
(0.0123)\end{array}$ & $\begin{array}{l}0.00909 \\
(0.0154)\end{array}$ & $\begin{array}{c}-0.00953 \\
(0.0111)\end{array}$ & $\begin{array}{l}-0.0195 \\
(0.0131)\end{array}$ & $\begin{array}{l}0.00563 \\
(0.0128)\end{array}$ & $\begin{array}{l}-0.0217 \\
(0.0164)\end{array}$ \\
\hline Manufacturing - Medium & $\begin{array}{l}-0.0187 \\
(0.0121)\end{array}$ & $\begin{array}{l}-0.0287^{\star} \\
(0.0171)\end{array}$ & $\begin{array}{l}-0.0269 \\
(0.0172)\end{array}$ & $\begin{array}{l}-0.00585 \\
(0.0353)\end{array}$ & $\begin{array}{c}-0.0293^{\star *} \\
(0.0123)\end{array}$ & $\begin{array}{l}-0.0377^{* *} \\
(0.0177)\end{array}$ & $\begin{array}{c}-0.0345^{\star *} \\
(0.0173)\end{array}$ & $\begin{array}{l}-0.0163 \\
(0.0352)\end{array}$ \\
\hline Manufacturing - High & $\begin{array}{l}-0.00732 \\
(0.00951)\end{array}$ & $\begin{array}{l}-0.0162 \\
(0.0142)\end{array}$ & $\begin{array}{l}-0.00527 \\
(0.0112)\end{array}$ & $\begin{array}{l}-0.0100 \\
(0.0151)\end{array}$ & $\begin{array}{c}-0.0424^{\star \star \star} \\
(0.0141)\end{array}$ & $\begin{array}{c}-0.0461^{\star \star \star} \\
(0.0164)\end{array}$ & $\begin{array}{c}-0.0335^{\star *} \\
(0.0142)\end{array}$ & $\begin{array}{r}-0.0413^{* *} \\
(0.0176)\end{array}$ \\
\hline Services - Low & $\begin{array}{c}-0.0239 * * \\
(0.0107)\end{array}$ & $\begin{array}{c}-0.0452^{\star \star \star} \\
(0.0160)\end{array}$ & $\begin{array}{l}-0.0273^{*} \\
(0.0141)\end{array}$ & $\begin{array}{c}-0.000339 \\
(0.0237)\end{array}$ & $\begin{array}{c}-0.0328^{\star *} \\
(0.0135)\end{array}$ & $\begin{array}{c}-0.0478 * \star \star \\
(0.0176)\end{array}$ & $\begin{array}{l}-0.0305^{\star} \\
(0.0165)\end{array}$ & $\begin{array}{r}-0.00456 \\
(0.0239)\end{array}$ \\
\hline Services - Medium & $\begin{array}{l}-0.00209 \\
(0.00704)\end{array}$ & $\begin{array}{c}-0.00696 \\
(0.0123)\end{array}$ & $\begin{array}{l}-0.00465 \\
(0.00795)\end{array}$ & $\begin{array}{l}0.0195^{\star} \\
(0.0112)\end{array}$ & $\begin{array}{c}-0.0115 \\
(0.00769)\end{array}$ & $\begin{array}{l}-0.0125 \\
(0.0123)\end{array}$ & $\begin{array}{c}-0.0132 \\
(0.00837)\end{array}$ & $\begin{array}{c}0.0105 \\
(0.0115)\end{array}$ \\
\hline Services - High & $\begin{array}{l}0.0406 * \star \\
(0.0177)\end{array}$ & $\begin{array}{l}0.0536^{\star} \\
(0.0273)\end{array}$ & $\begin{array}{c}0.0284 \\
(0.0207)\end{array}$ & $\begin{array}{c}0.0743^{\star \star \star} \\
(0.0250)\end{array}$ & $\begin{array}{l}0.0387^{\star} \\
(0.0204)\end{array}$ & $\begin{array}{l}0.0537^{\star} \\
(0.0285)\end{array}$ & $\begin{array}{c}0.0278 \\
(0.0225)\end{array}$ & $\begin{array}{r}0.0683^{\star \star \star} \\
(0.0262)\end{array}$ \\
\hline
\end{tabular}


offshoring is found to impact negatively upon employment in medium- and high-tech manufacturing and in low-tech services, with low-educated workers most affected. A positive effect of services offshoring is also observed for high-tech services however, with high- and to a lesser extent low-tech employment affected.

\section{Summary and conclusions}

In this paper we examine the impact of offshoring on labour demand elasticites for a sample of 40 countries over the period 1995-2009. In our analysis we consider both narrow and broad measures of offshoring and further distinguish between manufacturing and services offshoring. In addition, to estimating the impact of offshoring on total employment we also consider the effects on employment of different education type. We estimate a conditional and an unconditional labour demand model - the former providing an estimate of the technology or substitution effect of offshoring and the latter the overall effect of offshoring on employment. The models are estimated on all industries and we further split the industries according to technology level to allow for different impacts of offshoring across industries.

Results when considering total employment tend to suggest that while there has been a negative substitution effect of narrow offshoring the overall effect of offshoring has tended to be neutral, implying that output has responded positively to narrow offshoring offsetting the negative substitution effect. When considering broad offshoring the results indicate that the output effect has exceeded the substitution effect, such that the overall impact of offshoring on employment has been positive. Similar results are found for manufacturing offshoring, though services offshoring is found to have a negative effect on employment. Despite this, the results tend to suggest that there is little evidence of an overall negative impact of offshoring on employment.

This broad conclusion hides significant differences across industry and employment types. When splitting our sample into different industry types and when considering employment by different education types, the results suggest that particular industries and particular workers are affected by offshoring. While there are few significant negative effects of the various different offshoring measures we do observe significant negative effects of services offshoring in medium- and high-tech manufacturing industries and for low- and mediumeducated employment in particular. The positive effects of the other offshoring measures tend to be concentrated in high-tech manufacturing industries and for high-education employment. The results suggest that it is in these industries in which access to (relatively cheap) inputs from abroad can enhance productivity and output, which in turn increases employment (of high-skilled labour). 
To conclude, the results presented above provide a mixed bag of results. In general, the results tend to support the view that both the narrow and the broad measure of offshoring and the measure of manufacturing offshoring have an overall neutral or slightly positive effect on employment, with the negative technology effect offset by a positive scale effect. This general result hides differences across both industry and employment types however, suggesting that the composition of employment both within and across industries may well be affected by offshoring. 


\section{References}

Amiti, M. and S-J. Wei, 2005. Service offshoring, productivity, and employment: Evidence from the United States. IMF Working Paper no. 05/238, International Monetary Fund.

Arndt, S., 1997. Globalization and the open economy. North American Journal of Economics and Finance, 8, 71-79.

Bruno, G.S.F., Falzoni, A.M. and R. Helg, 2004. Measuring the effect of globalisation on labour demand elasticity: An empirical application to OECD countries. Working Paper no. 153, CESPRI University, Milan.

Cadarso, M.A., Gomez, N., Lopez, L.A. and M.A. Tobarra, 2008. The EU enlargement and the impact of outsourcing on industrial employment in Spain, 1993-2003. Structural Change and Economic Dynamics, 19(1), 95-108.

Campa, J. and L.S. Goldberg, 1997. The evolving external orientation of manufacturing: A profile of four countries. Economic Policy Review, Federal Reserve Bank of New York, 53-81.

Cappariello, R.,2010. The implications of international outsourcing on employment: Estimates for the Italian manufacturing industry. Mimeo, Bank of Italy.

Falk, M. and B.M. Wolfmayr, 2005. Employment effects of outsourcing to low wage countries: Empirical evidence for EU countries. WIFO Working Paper no. 262, WIFO.

Feenstra, R.C., 2007. Globalization and its impact on labor. Presented as the Global Economy Lecture, Vienna Institute for International Economic Studies (wiiw).

Feenstra, R.C. and G.H. Hanson, 1996. Foreign investment outsourcing and relative wages. In R.C. Feenstra, G.M. Grossman and D.A. Irwin (eds.), The Political Economy of Trade Policy: Papers in Honor of Jagdish Bhagwati, Cambridge: MA, The MIT Press, pp. 89-127.

Feenstra, R.C. and G.H. Hanson, 1999. The impact of outsourcing and high-technology capital on wages: Estimates for the United States, 1979-1990. Quarterly Journal of Economics, 114, 907-941.

Hijzen. A., Görg, H. and R.C. Hine, 2005. International outsourcing and the skill structure of labour demand in the United Kingdom. Economic Journal, 115, 860-878.

Hijzen, A. and P. Swaim, 2007. Does offshoring reduce industry employment? GEP Research Paper no. 2007/24, The Leverhulme Centre for Research on Globalisation and Economic Policy, the University of Nottingham.

Hijzen, A. and P. Swaim, 2010. Offshoring, labour market institutions and the elasticity of labour demand. European Economic Review, 54, 1016-1034.

Jensen, J.B., 2011. Fear and Offshoring: The Facts on Global Services Outsourcing. Institute for International Economics, Washington, DC.

Michaels, G., Natraj, A. and J. van Reenen, 2010. Has ICT polarized skill demand? Evidence from eleven countries over 25 years. Mimeo, London School of Economics.

Molnar, M., Pain, N. and D. Taglioni, 2007. The internationalization of production, international outsourcing and employment in the OECD. OECD Economics Department Working Paper no. 561, Paris.

OECD, 2007. Offshoring and employment: Trends and policy implications. Paris, OECD.

Schöller, D., 2007. Service offshoring and the demand for less-skilled labor: Evidence from Germany. Mimeo, University of Hohenheim.

Slaughter, M., 2000. What are the results of product-price studies and what can we learn from their differences? In Feenstra, R.C. (ed.), The Impact of International Trade on Wages, The University of Chicago Press.

Slaughter, M., 2001. International trade and labor-demand elasticities. Journal of International Economics, 54, 27-56. 


\section{Appendix}

Table A1

\section{Industries and Industry Classification}

\begin{tabular}{|c|c|c|}
\hline Code & Industry & Type \\
\hline AtB & Agriculture, Hunting, Forestry and Fishing & M/Low \\
\hline $\mathrm{C}$ & Mining and Quarrying & M/Med \\
\hline $15 \mathrm{t} 16$ & Food, Beverages and Tobacco & M/Low \\
\hline $17 \mathrm{t} 18$ & Textiles and Textile Products & M/Low \\
\hline 19 & Leather, Leather and Footwear & M/Low \\
\hline 20 & Wood and Products of Wood and Cork & M/Low \\
\hline $21 \mathrm{t} 22$ & Pulp, Paper, Paper, Printing and Publishing & M/Med \\
\hline 23 & Coke, Refined Petroleum and Nuclear Fuel & M/Med \\
\hline 24 & Chemicals and Chemical Products & M/High \\
\hline 25 & Rubber and Plastics & M/Med \\
\hline 26 & Other Non-Metallic Mineral & M/Low \\
\hline $27 \mathrm{t} 28$ & Basic Metals and Fabricated Metal & M/Low \\
\hline 29 & Machinery, Nec & M/High \\
\hline $30 \mathrm{t} 33$ & Electrical and Optical Equipment & M/High \\
\hline $34 \mathrm{t} 35$ & Transport Equipment & M/High \\
\hline $36 \mathrm{t} 37$ & Manufacturing, Nec; Recycling & M/Med \\
\hline E & Electricity, Gas and Water Supply & S/Med \\
\hline $\mathrm{F}$ & Construction & S/Low \\
\hline 50 & Sale, Maintenance and Repair of Motor Vehicles and Motorcycles; Retail Sale of Fuel & S/Low \\
\hline 51 & Wholesale Trade and Commission Trade, Except of Motor Vehicles and Motorcycles & S/Med \\
\hline 52 & Retail Trade, Except of Motor Vehicles and Motorcycles; Repair of Household Goods & S/Med \\
\hline $\mathrm{H}$ & Hotels and Restaurants & S/Low \\
\hline 60 & Inland Transport & S/Med \\
\hline 61 & Water Transport & S/Med \\
\hline 62 & Air Transport & S/High \\
\hline 63 & Other Supporting and Auxiliary Transport Activities; Activities of Travel Agencies & S/Med \\
\hline 64 & Post and Telecommunications & S/Med \\
\hline $\mathrm{J}$ & Financial Intermediation & S/High \\
\hline 70 & Real Estate Activities & S/Med \\
\hline $71 \mathrm{t} 74$ & Renting of M\&Eq and Other Business Activities & S/High \\
\hline L & Public Admin and Defence; Compulsory Social Security & S/High \\
\hline M & Education & S/High \\
\hline $\mathrm{N}$ & Health and Social Work & S/High \\
\hline $\mathrm{O}$ & Other Community, Social and Personal Services & S/High \\
\hline$P$ & Private Households with Employed Persons & S/High \\
\hline
\end{tabular}

Notes: M/Low - Low-tech manufacturing; M/Med - Medium-tech manufacturing; M/High - High-tech manufacturing; S/Low Low-tech services; S/Med - Medium-tech services; S/High - High-tech services 


\section{Short list of the most recent wiiw publications (as of July 2012)}

For current updates and summaries see also wiiw's website at www.wiiw.ac.at

Offshoring and the Elasticity of Labour Demand by Neil Foster, Johannes Pöschl and Robert Stehrer

wiiw Working Papers, No. 90, July 2012 23 pages including 7 Tables and 4 Figures hardcopy: EUR 8.00 (PDF: free download from wiiw's website)

Manufacturing Productivity: Effects of Service Sector Innovations and Institutions by Neil Foster, Johannes Pöschl and Robert Stehrer

wiiw Working Papers, No. 89, July 2012

15 pages including 5 Tables

hardcopy: EUR 8.00 (PDF: free download from wiiw's website)

Surveying Romanian Migrants in Italy Before and After the EU Accession: Migration Plans, Labour Market Features and Social Inclusion

by Isilda Mara

wiiw Research Reports, No. 378, July 2012

136 pages including 39 Tables and 112 Figures

hardcopy: EUR 24.00 (PDF: free download from wiiw's website)

\section{wiiw Monthly Report 7/12}

edited by Leon Podkaminer

- Financial balances of the private, foreign and public sectors: long-term tendencies for the European Union

- Labour hoarding during the crisis: Evidence for selected new member states from the Financial Crisis Survey

- The European banking crisis and spillover effects in the countries of CESEE revisited

- Statistical Annex: Selected monthly data on the economic situation in Central, East and Southeast Europe

wiiw, July 2012

30 pages including 11 Tables and 14 Figures

(exclusively for subscribers to the wiiw Service Package)

\section{Labour Hoarding during the Crisis: Evidence for selected New Member States from the Financial Crisis Survey}

by Sandra M. Leitner and Robert Stehrer

wiiw Working Papers, No. 84, June 2012

17 pages including 10 Tables and 1 Figure

hardcopy: EUR 8.00 (PDF: free download from wiiw's website) 


\section{Bilateral Exchange Rates and Jobs}

by Eddy Bekkers and Joseph Francois

wiiw Working Papers, No. 83, June 2012

31 pages including 2 Tables and 3 Figures

hardcopy: EUR 8.00 (PDF: free download from wiiw's website)

Import Prices, Income, and Inequality

by Eddy Bekkers, Joseph Francois and Miriam Manchin

wiiw Working Papers, No. 82, June 2012

44 pages including 4 Tables

hardcopy: EUR 8.00 (PDF: free download from wiiw's website)

\section{Trade in Value Added and the Valued Added in Trade \\ by Robert Stehrer}

wiiw Working Papers, No. 81, June 2012

20 pages including 7 Tables and 1 Figure

hardcopy: EUR 8.00 (PDF: free download from wiiw's website)

Wirtschaftsentwicklung divergiert in den kommenden Jahren auch in Mitteleuropa, Ost- und Südosteuropa zwischen Norden und Süden

by Vasily Astrov, Doris HanzI-Weiss, Mario Holzner and Sebastian Leitner

wiiw Research Papers in German language, June 2012

(reprinted from: WIFO-Monatsberichte, Vol. 85, No. 5, May 2012)

10 pages including 5 Tables and 4 Figures

hardcopy: EUR 8.00 (PDF: free download from wiiw's website)

\section{Value Added and Factors in Trade: A Comprehensive Approach}

by Robert Stehrer, Neil Foster and Gaaitzen de Vries

wiiw Working Papers, No. 80, June 2012

23 pages including 9 Tables

hardcopy: EUR 8.00 (PDF: free download from wiiw's website)

\section{wiiw Monthly Report 6/12}

edited by Leon Podkaminer

- The transformation of international financial markets and the future of the eurozone

- The harmonisation of banking supervision: a chokehold

- The impact of offshoring on the skill structure of labour demand

- Statistical Annex: Selected monthly data on the economic situation in Central, East and Southeast Europe

wiiw, June 2012

30 pages including 15 Tables and 4 Figures

(exclusively for subscribers to the wiiw Service Package) 


\section{International spillovers in a world of technology clubs}

by Roman Stöllinger

wiiw Working Papers, No. 79, May 2012

25 pages including 8 Tables and 3 Figures

hardcopy: EUR 8.00 (PDF: free download from wiiw's website)

\section{wiiw Monthly Report 5/12}

edited by Leon Podkaminer

- Interim Romanian government sworn in: any room for manoeuvring?

- Croatia's EU membership: lessons from earlier accessions

- The cold civil war in Poland

- Statistical Annex: Selected monthly data on the economic situation in Central, East and Southeast Europe

wiiw, May 2012

22 pages including 8 Tables

(exclusively for subscribers to the wiiw Service Package)

\section{wiiw Monthly Report 4/12}

edited by Leon Podkaminer

- Slovakia after the elections

- Labour market issues in Europe's Eastern and Western Balkan neighbours

- Net private savings in relation to the government's financial balance

- Statistical Annex: Selected monthly data on the economic situation in Central, East and Southeast Europe

wiiw, April 2012

28 pages including 10 Tables and 4 Figures

(exclusively for subscribers to the wiiw Service Package)

\section{Convergence of Knowledge-intensive Sectors and the EU's External Competitiveness}

by Robert Stehrer et al.

wiiw Research Reports, No. 377, April 2012

123 pages including 30 Tables and 60 Figures

hardcopy: EUR 8.00 (PDF: free download from wiiw's website)

\section{wiiw Monthly Report 3/12}

edited by Leon Podkaminer

- The European Union and the MENA countries: fostering North-South economic integration

- Europe's position in trade in knowledge-intensive business services

- What kind of socio-economic order do we need in Europe?

- Statistical Annex: Selected monthly data on the economic situation in Central, East and Southeast Europe

wiiw, March 2012

26 pages including 9 Tables and 5 Figures

(exclusively for subscribers to the wiiw Service Package) 


\section{wiiw Service Package}

The Vienna Institute offers to firms and institutions interested in unbiased and up-to-date information on Central, East and Southeast European markets a package of exclusive services and preferential access to its publications and research findings, on the basis of a subscription at an annual fee of EUR 2,000.

This subscription fee entitles to the following package of Special Services:

- A free invitation to the Vienna Institute's Spring Seminar, a whole-day event at the end of March, devoted to compelling topics in the economic transformation of the Central and East European region (for subscribers to the wiiw Service Package only).

- Copies of, or online access to, The Vienna Institute Monthly Report, a periodical consisting of timely articles summarizing and interpreting the latest economic developments in Central and Eastern Europe and the former Soviet Union. The statistical annex to each Monthly Report contains, alternately, country-specific tables or graphs with monthly key economic indicators, economic forecasts, the latest data from the wiiw Industrial Database and excerpts from the wiiw FDI Database. This periodical is not for sale, it can only be obtained in the framework of the wiiw Service Package.

- Free copies of the Institute's Research Reports (including Reprints), Current Analyses and Forecasts, Country Profiles and Statistical Reports.

- A free copy of the wiiw Handbook of Statistics (published in October/November each year and containing more than 400 tables and graphs on the economies of Albania, Bosnia and Herzegovina, Bulgaria, Croatia, the Czech Republic, Estonia, Hungary, Latvia, Lithuania, Macedonia, Montenegro, Poland, Romania, Russia, Serbia, the Slovak Republic, Slovenia and Ukraine)

- Free online access to the wiiw Monthly Database, containing more than 1200 leading indicators monitoring the latest key economic developments in ten Central and East European countries.

- Consulting. The Vienna Institute is pleased to advise subscribers on questions concerning the East European economies or East-West economic relations if the required background research has already been undertaken by the Institute. We regret we have to charge extra for ad hoc research.

- Free access to the Institute's specialized economics library and documentation facilities.

Subscribers who wish to purchase wiiw data sets on CD-ROM or special publications not included in the wiiw Service Package are granted considerable price reductions.

For detailed information about the wiiw Service Package please visit wiiw's website at www.wiiw.ac.at 
The Vienna Institute

for International Economic Studies

Rahlgasse 3

A-1060 Vienna

O Please forward more detailed information about the Vienna Institute's Service Package

O Please forward a complete list of the Vienna Institute's publications to the following address

Please enter me for

O 1 yearly subscription of Research Reports (including Reprints) at a price of EUR 120.00 (hardcopy, Austria), EUR 135.00 (hardcopy, Europe), EUR 155.00 (hardcopy, overseas) and EUR 48.00 (PDF download with password) respectively

O 1 yearly subscription of Current Analyses and Forecasts a price of EUR 150.00 (hardcopy, Austria), EUR 155.00 (hardcopy, Europe), EUR 170.00 (hardcopy, overseas) and EUR 120.00 (PDF download with password) respectively

Please forward

O the following issue of Research Reports

$\bigcirc$ the following issue of Current Analyses and Forecasts

the following issue of Working Papers

$\bigcirc$ the following issue of Research Papers in German language

O the following issue of wiiw Database on Foreign Direct Investment

O the following issue of wiiw Handbook of Statistics

$\bigcirc$ (other)

Name

Address

Telephone

Fax

E-mail

Date

Signature

Herausgeber, Verleger, Eigentümer und Hersteller:

Verein „Wiener Institut für Internationale Wirtschaftsvergleiche“ (wiiw),

Wien 6, Rahlgasse 3

ZVR-Zahl: 329995655

Postanschrift: $\quad$ A-1060 Wien, Rahlgasse 3, Tel: [+431] 53366 10, Telefax: [+431] 533661050

Internet Homepage: www.wiiw.ac.at

Nachdruck nur auszugsweise und mit genauer Quellenangabe gestattet.

P.b.b. Verlagspostamt 1060 Wien 